\title{
Archaeological Inventory of 216 Acres of Martindale Army Aviation Support Facility, San Antonio, Bexar County, Texas
}

Cynthia Moore Munoz

Center for Archeological Research, University of Texas at San Antonio

Follow this and additional works at: https://scholarworks.sfasu.edu/ita

Part of the American Material Culture Commons, Archaeological Anthropology Commons, Environmental Studies Commons, Other American Studies Commons, Other Arts and Humanities Commons, Other History of Art, Architecture, and Archaeology Commons, and the United States History Commons

Tell us how this article helped you.

This Article is brought to you for free and open access by the Center for Regional Heritage Research at SFA ScholarWorks. It has been accepted for inclusion in Index of Texas Archaeology: Open Access Gray Literature from the Lone Star State by an authorized editor of SFA ScholarWorks. For more information, please contact cdsscholarworks@sfasu.edu. 


\section{Archaeological Inventory of 216 Acres of Martindale Army Aviation Support Facility, San Antonio, Bexar County, Texas}

\section{Licensing Statement}

This is a work produced for the Texas Department of Transportation (TxDOT) by the report producer. TxDOT and the report producer jointly own all rights, title, and interest in and to all intellectual property developed under TXDOT's contract with the report producer. The report may be cited and brief passages from this publication may be reproduced without permission provided that credit is given to both TXDOT and the report producer. Permission to reprint an entire chapter, section, figures or tables must be obtained in advance from either the Supervisor of the Archeological Studies Branch, Environmental Affairs Division, Texas Department of Transportation, 125 East 11th Street, Austin, Texas, 78701 or from the report producer. 


\section{Archaeological Inventory of 216 Acres of Martindale}

\section{Army Aviation Support Facility, San Antonio,}

Bexar County, Texas
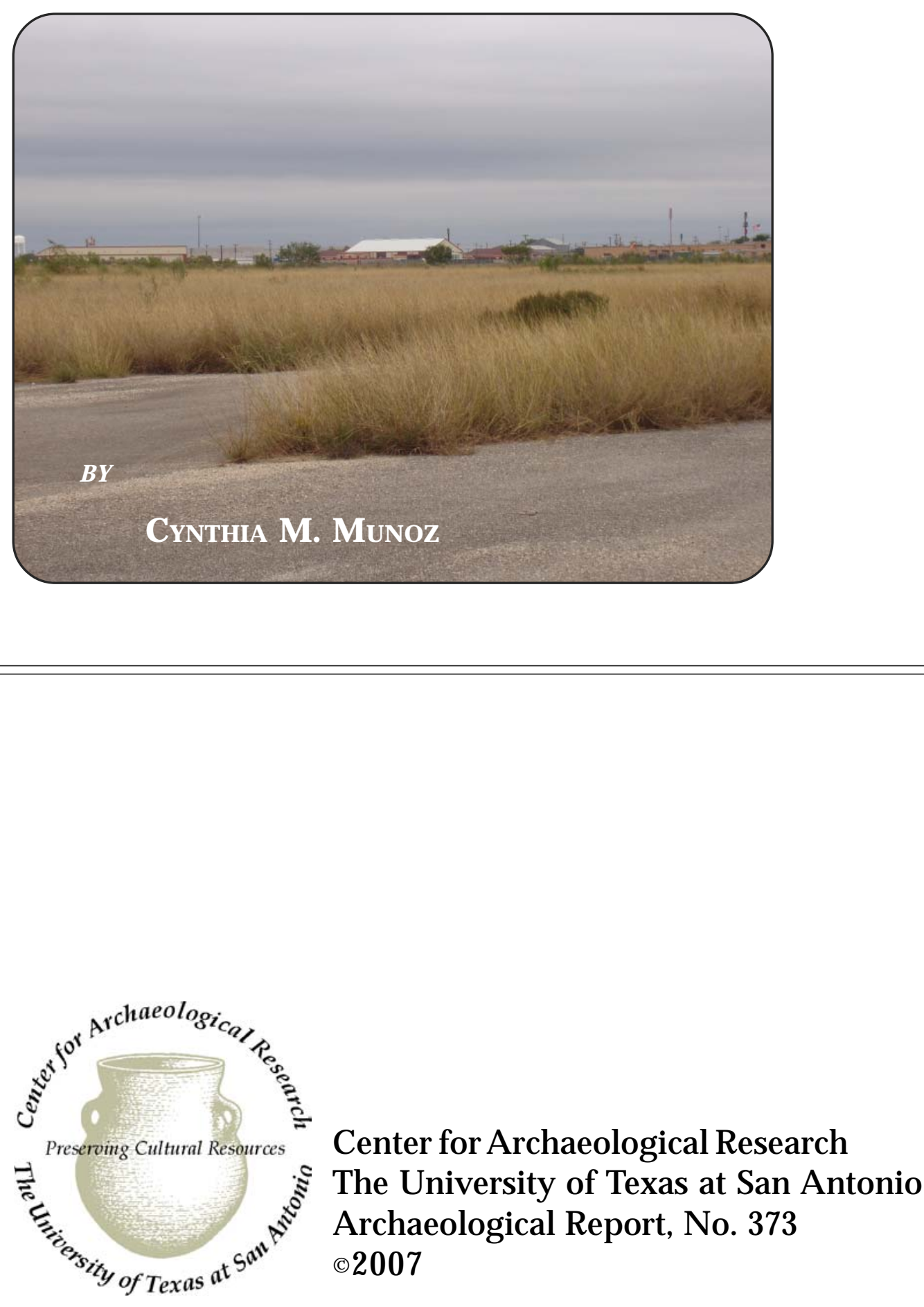


\title{
Archaeological Inventory of 216 Acres of Martindale Army Aviation Support Facility, San Antonio, Bexar County, Texas
}

\author{
by \\ Cynthia M. Munoz
}

Texas Antiquities Permit No. 4272

Principal Investigator

Raymond P. Mauldin

Prepared for

Cultural Resources Management Program

Adjutant General's Department

P.O. Box 5218

Austin, Texas 78763-5218

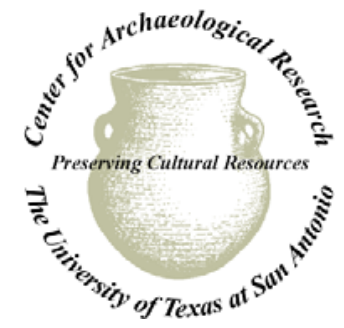

Prepared by

Center for Archaeological Research

The University of Texas at San Antonio

Archaeological Report, No. 373

(C)2007 
A list of publications offered by the Center for Archaeological Research is available. Call (210) 458-4378; write to the Center for Archaeological Research, The University of Texas at San Antonio, One UTSA Circle, San Antonio, Texas 78249-1644; e-mail to car@utsa.edu; or visit CAR’s web site at http://car.utsa.edu. 


\section{Abstract}

During the fall of 2006 (October 24 through November 3, 2006), the Center for Archaeological Research (CAR) of The University of Texas at San Antonio conducted an archaeological inventory of the Army National Guard Martindale Army Aviation Support Facility (AASF) located in Bexar County, Texas for the Adjutant General's Office. No plans for construction on the facility are proposed.

The work was performed under Texas Antiquities Permit No. 4272, with Dr. Raymond Mauldin, CAR Assistant Director, serving as Principal Investigator and Cynthia Moore Munoz serving as the Project Archaeologist. The inventory consisted of a 100 percent pedestrian survey accompanied by shovel testing of approximately 121 acres of open land on the 216-acre Army National Guard Martindale AASF.

No features were observed within the project area. In the process of conducting the survey one new site was identified and documented, 41BX1694. This site is located along the eastern boundary of the property and consists of a scatter of burned rock, debitage, a tool and a tested cobble. All of the artifacts were encountered in the top $30 \mathrm{~cm}$ of sediments. Due to the disturbed nature of the top $30 \mathrm{~cm}$ of the project area from bioturbation, rodent activity and soil tilling, and to the low density of cultural remains, the site appears to retain minimal research potential. However, due to the close proximity of Rosillo Creek and the presence of alluvial soils the possibility exists for deeply buried features and/or cultural material on the eastern side of the facility. Because the survey consisted of shovel testing the upper $60 \mathrm{~cm}$ of sediments, any deeply buried deposits were not assessed. Therefore CAR recommends that 41BX1694 be considered potentially eligible for nomination to the National Register of Historic Places.

Artifacts collected during this project were prepared for curation according to Texas Historical Commission guidelines and are curated at the Texas Archeological Research Laboratory at the University of Texas at Austin. 


\section{Table of Contents}

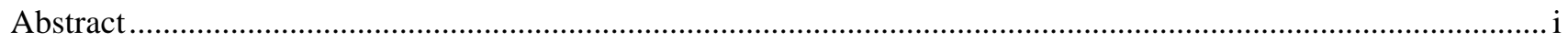

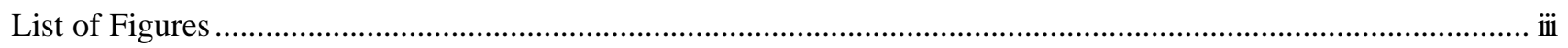

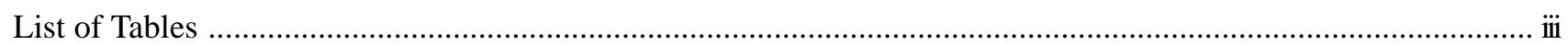

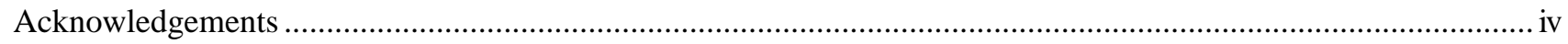

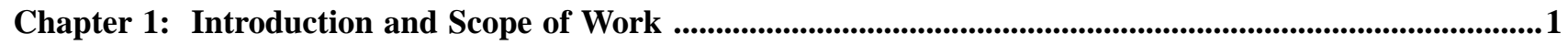

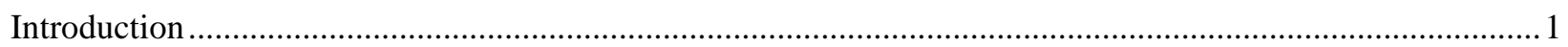

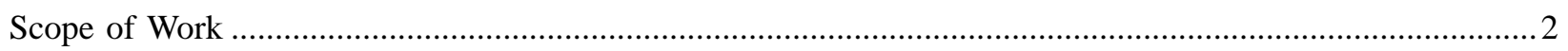

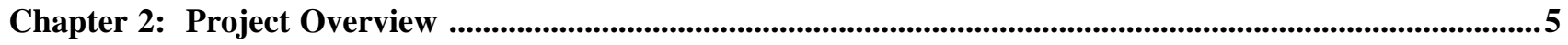

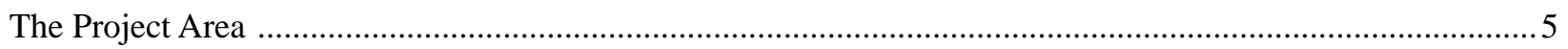

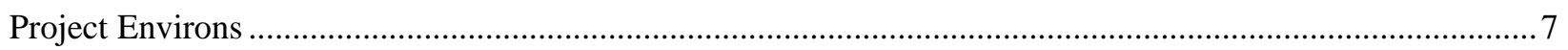

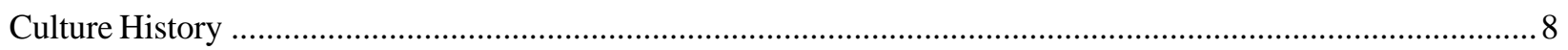

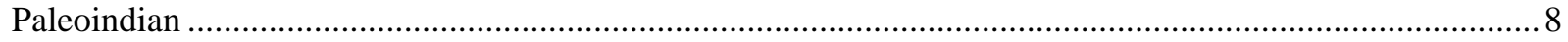

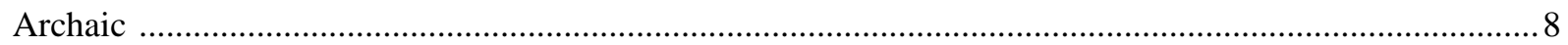

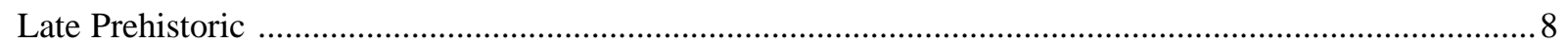

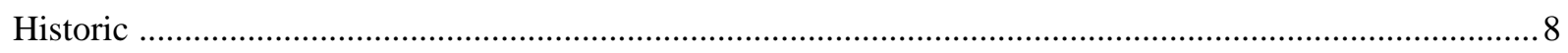

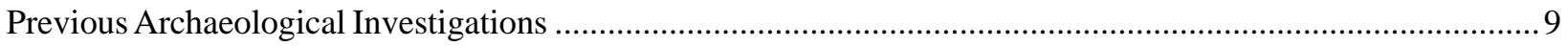

Chapter 3: Field and Laboratory Methods .................................................................................................. 11

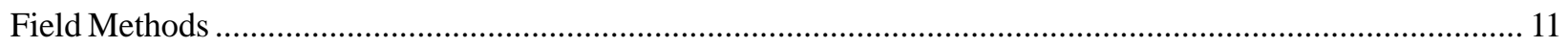

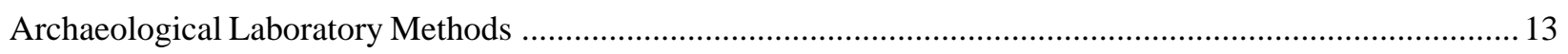

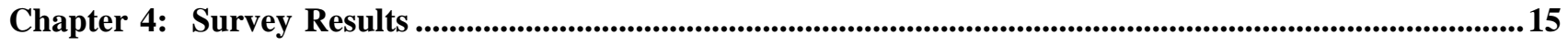

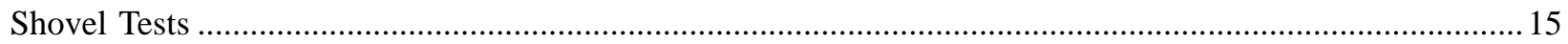

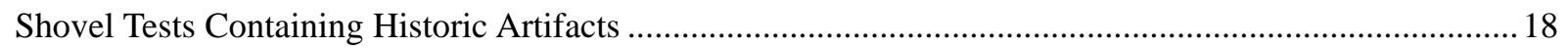

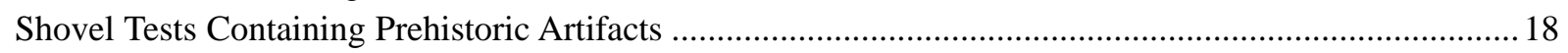

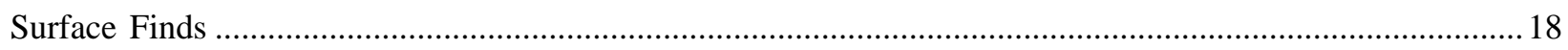

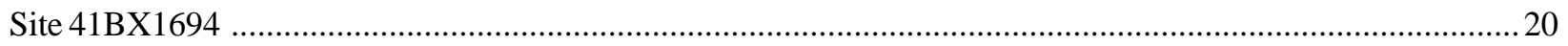

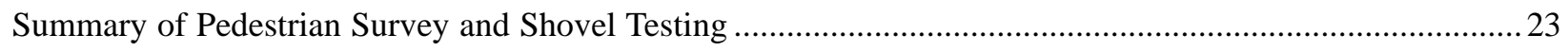

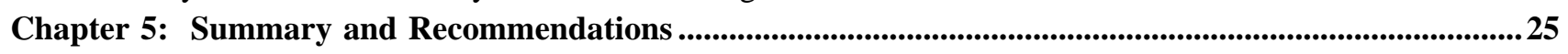

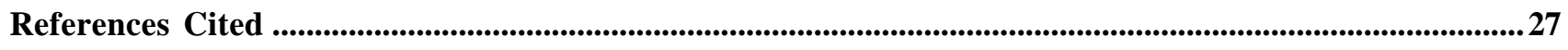




\section{List of Figures}

Figure 1-1. Location of the Martindale Army Aviation Support Facility. 1

Figure 1-2. Aerial photograph of Martindale Army Aviation Support Facility (proposed survey area indicated by yellow hatching).

Figure 1-3. Project area on the San Antonio East and Martinez, Texas 7.5-minute series USGS

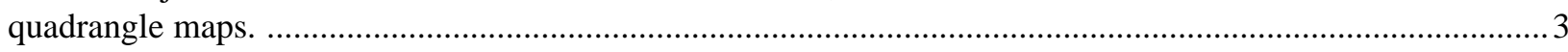

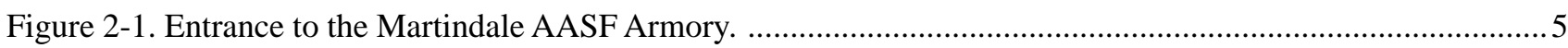

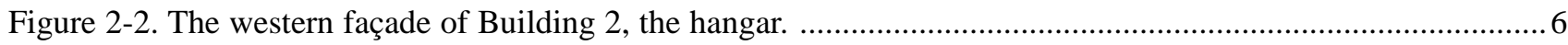

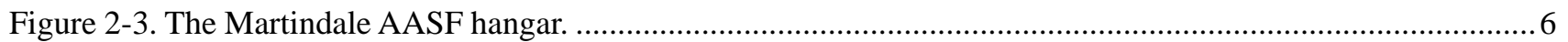

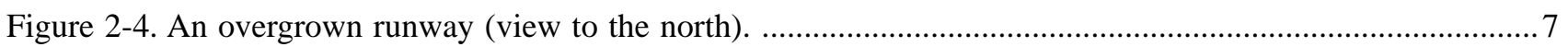

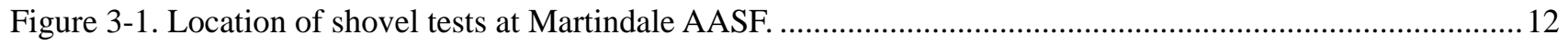

Figure 4-1. Termination of Shovel Test 44 at $19 \mathrm{~cm}$ below surface .............................................................15

Figure 4-2. Soil map of Martindale AASF including drainage on the eastern side of the project area. .................... 16

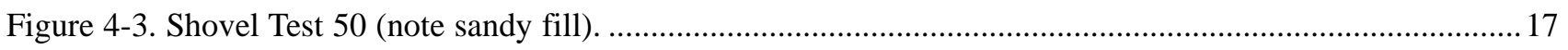

Figure 4-4. Artificial drainage leading to basin on the southeastern edge of the project area. ............................ 17

Figure 4-5. Artificial drainage basin on the southeastern edge of the project area. ............................................ 18

Figure 4-6. Location of shovel tests indicating positive for historic (yellow) and prehistoric (red) finds............... 19

Figure 4-7. Artifacts encountered during survey: (a) bifacially retouched tool; (b) bifacial core. ..........................220

Figure 4-8. Location of isolated finds along the eastern edge of the project area. ..........................................2 21

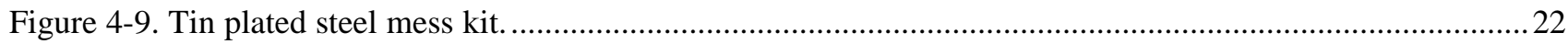

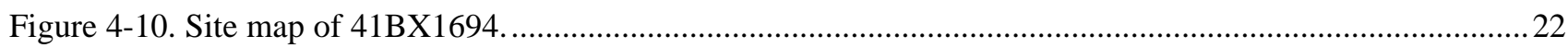

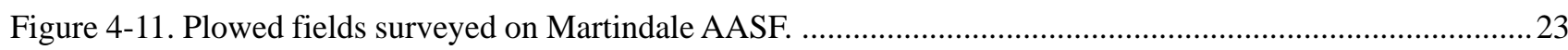

\section{List of Tables}

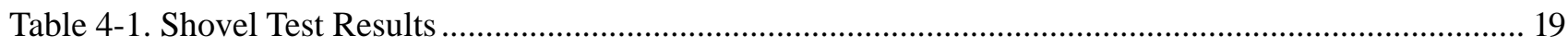

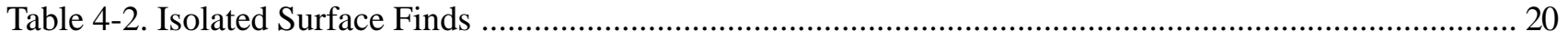




\section{Acknowledgments}

The author would like to thank Chief Warrant Officer 3 Xavier Gudino, the Operations Manager at Martindale AASF and Kristen Wenzel of the Cultural Resources Management Program in the Adjutant General's Office for their assistance. Dr. Raymond Mauldin, CAR Assistant Director, served as Principal Investigator on the project. The successful completion of this project is owed in a large part to the able and hard-working field crew, Leonard Kemp and Jason Perez. Thank you for putting up with the rain and mud when I insisted we continue. Bruce Moses and Leonard Kemp prepared the graphics for the project and the final report. Claudia Branton edited the final manuscript. The help of one and all is greatly appreciated. 


\section{Chapter 1: Introduction and Scope of Work}

\section{Introduction}

The Center for Archaeological Research (CAR) of The University of Texas at San Antonio conducted an archaeological inventory of the Army National Guard Martindale Army Aviation Support Facility located in Bexar County, Texas in November 2006 for the Adjutant General's Office. The inventory consisted of a 100 percent pedestrian survey accompanied by shovel testing of approximately 121 acres of open land on the 216-acre Army National Guard Martindale AASF (Figure 1-1). The work was performed under Texas Antiquities Permit No. 4272, with Dr. Raymond Mauldin, CAR Assistant Director, serving as Principal Investigator.
Martindale AASF supports the Texas Army National Guard Aviation Unit. This unit supports the state of Texas by responding to natural disasters and the United States government by serving in the Iraq War. Historically, the facility was used to train flight instructors during World War II (Thompson 2006). The airfield's four main structures, an Operations Building, an Armory, a hangar, and a garage for helicopter storage, are surrounded by approximately 121 acres of open plowed fields. Runways, overgrown since helicopters replaced airplanes at the facility, traverse the eastern side of the property north to south (Figure 1-2). Martindale is located in southeast San Antonio immediately adjacent to the southeast quadrant of the IH-10 and Loop 410 interchange. Figure 1-3 illustrates the facility on the San Antonio East and the Martinez, Texas USGS 7.5-minute quadrangle maps.

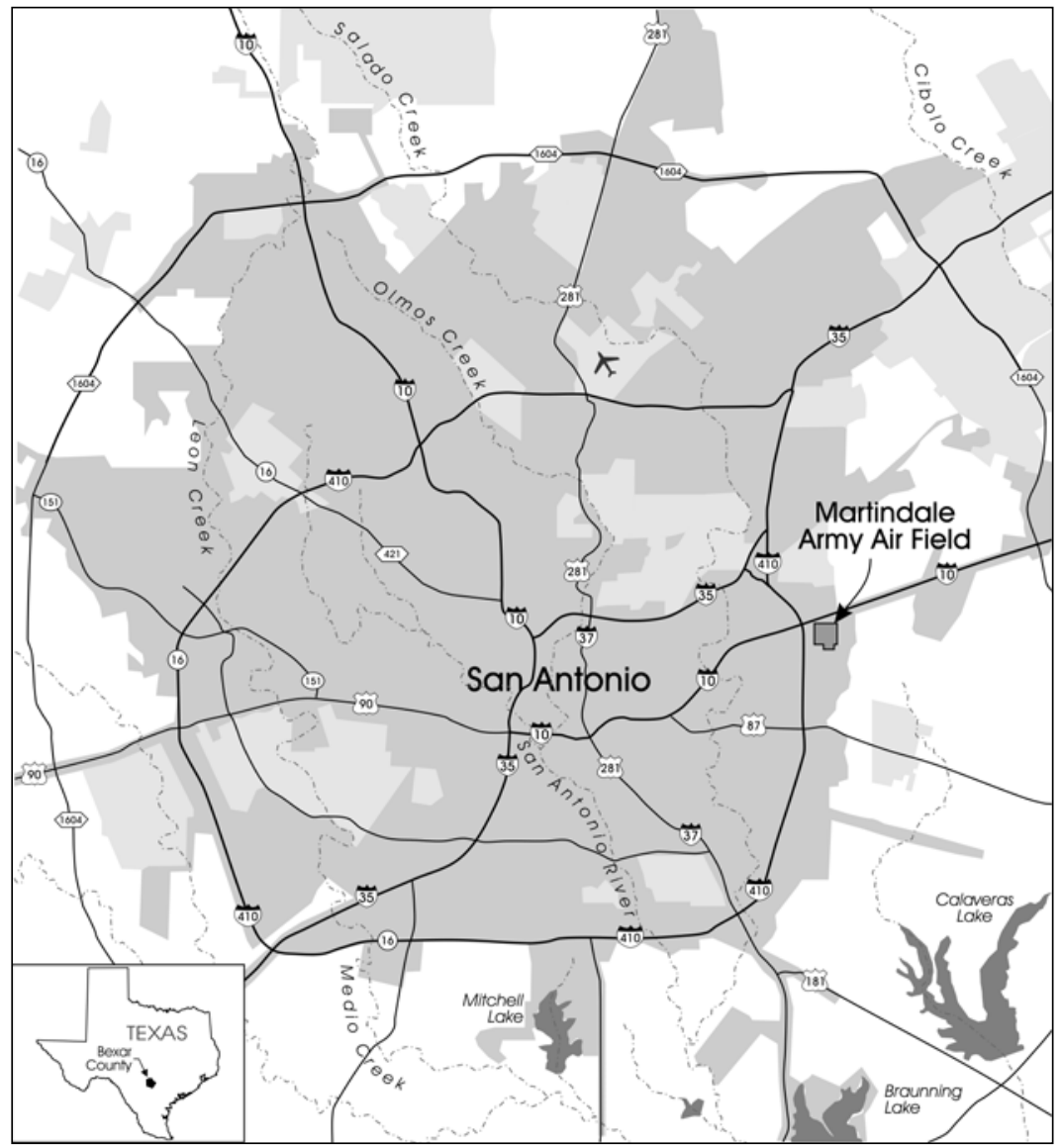

Figure 1-1. Location of the Martindale Army Aviation Support Facility. 


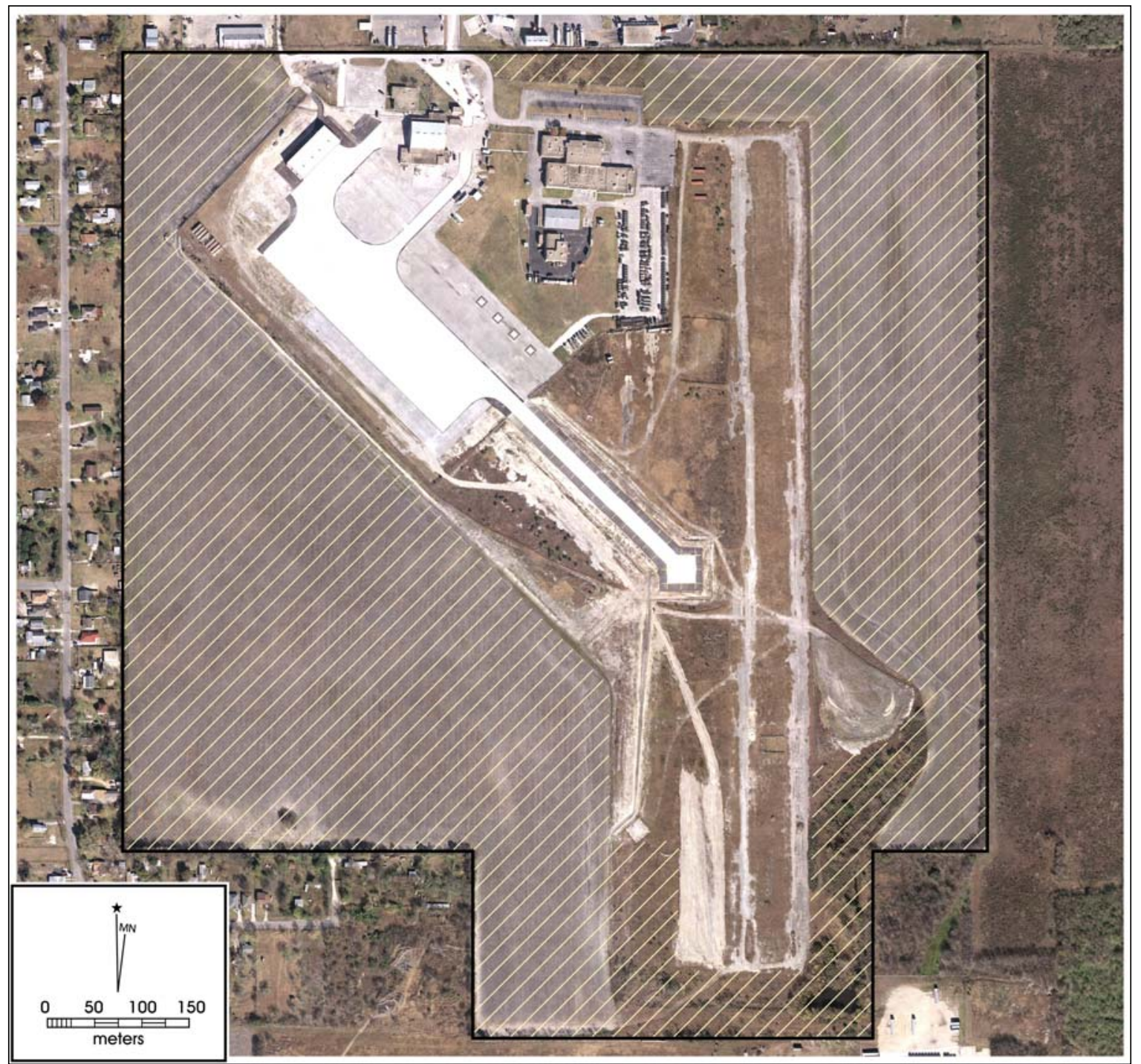

Figure 1-2. Aerial photograph of Martindale Army Aviation Support Facility (proposed survey area indicated by yellow hatching).

In the process of conducting the 100 percent pedestrian survey of the facility one new site was identified and documented, 41BX1694. This site is located along the eastern boundary of the property and is discussed in detail in Chapter 4.

This document summarizes the results of the fieldwork and provides recommendations regarding the management and National Register of Historic Places (NRHP) eligibility of cultural resources located on this facility. This report consists of five chapters. Following this introductory chapter, which closes with the presentation of the scope of work, Chapter 2 provides a brief overview of the project area and summarizes the archaeological knowledge about the region. Chapter 3 discusses the fieldwork and laboratory methodology employed during the project. The results of the archaeological survey are presented in detail in Chapter 4. Chapter 5 summarizes the work and provides recommendations for site 41BX1694.

\section{Scope of Work}

The primary goal of the pedestrian survey was to locate and document all prehistoric and/or historic archaeological sites within the project area. Specifically, CAR was responsible for the following: 


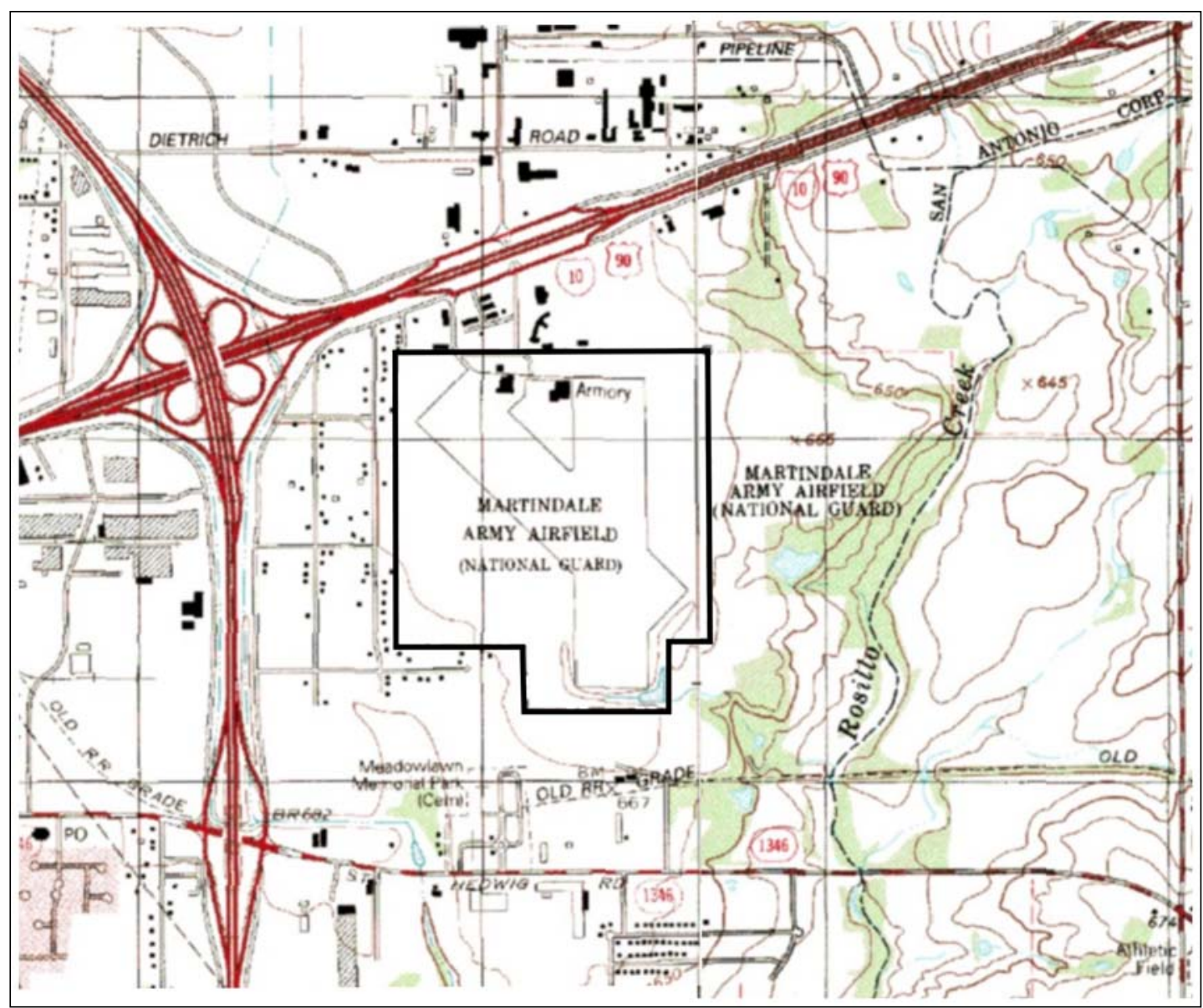

Figure 1-3. Project area on the San Antonio East and Martinez, Texas 7.5-minute series USGS quadrangle maps.

1. Conducting background research to determine previous archaeological investigations, locate historic aerial photos, and gather available archival information;

2. Undertaking an intensive 100 percent pedestrian survey accompanied by shovel testing of the approximately 121 acres of open fields surrounding the 216-acre airfield facility in accordance with the standards established by Texas Historical Commission (THC);

3. Completing Texas Archeological Site Data Forms;

4. Preparing all collected materials and all associated documents for curation at the Texas Archeological Research Laboratory;
5. Producing a report containing a historic background, survey methodology, site descriptions with maps and photographs, and recommendations for NRHP eligibility and management; and

6. Submitting GIS layers reflecting shovel test locations and site boundaries along with database files of artifact catalogs, photographs (scanned or digital) and associated logs, scanned site forms and maps. 



\section{Chapter 2: Project Overview}

This chapter presents a brief description of the Martindale AASF and characterizes the project area environs and culture history. The chapter concludes with a summary of previous archaeological work conducted in the vicinity of the facility.

\section{The Project Area}

The project area is located on the San Antonio East and Martinez, Texas 7.5-minute series quadrangle maps immediately adjacent to the southeast quadrant of the IH-10 and Loop 410 interchange (Figure 1-3). The project area lies approximately $450 \mathrm{~m}$ to the west of the Rosillo Creek drainage. Martindale AASF is situated on 216 acres bordered on the west by residential neighborhoods and on the north and south by commercial buildings. Land to the east of the facility is undeveloped. The facility consists of an armory, hangars, related buildings, helicopter pads, and runways (Figures 2-1, $2-2,2-3$, and 2-4). The survey area consists of approximately 121 acres of plowed open field (Figure 1-2).
Martindale AASF was acquired by the United States government along with other small airfields as a support facility to Randolph Field to facilitate the United States' rapid expansion of air power. The property was purchased from Mrs. Ethel Martindale Calhoun in 1944 for ten dollars (Bexar County Clerk 2007). The United States Army used the Martindale property as one of many small support airfields for the Randolph Army Air Corps facility for pilot training. Because the Army Air Corps no longer needed extra runways after World War II, they agreed to allow the Texas National Guard, the Air National Guard, and the Civil Air Patrol to use the airfield. Martindale remained a possession of the federal government until 1954 when the state acquired the property (DMN, 9 August 1954:8). The Texas Army National Guard Aviation unit used the airfield to fly reconnaissance missions through the late 1950s. Helicopters gradually replaced the airplanes and were used for MedEvac during the Korean War. Today pilots at Martindale fly UH-60 Black Hawk helicopters for pilot

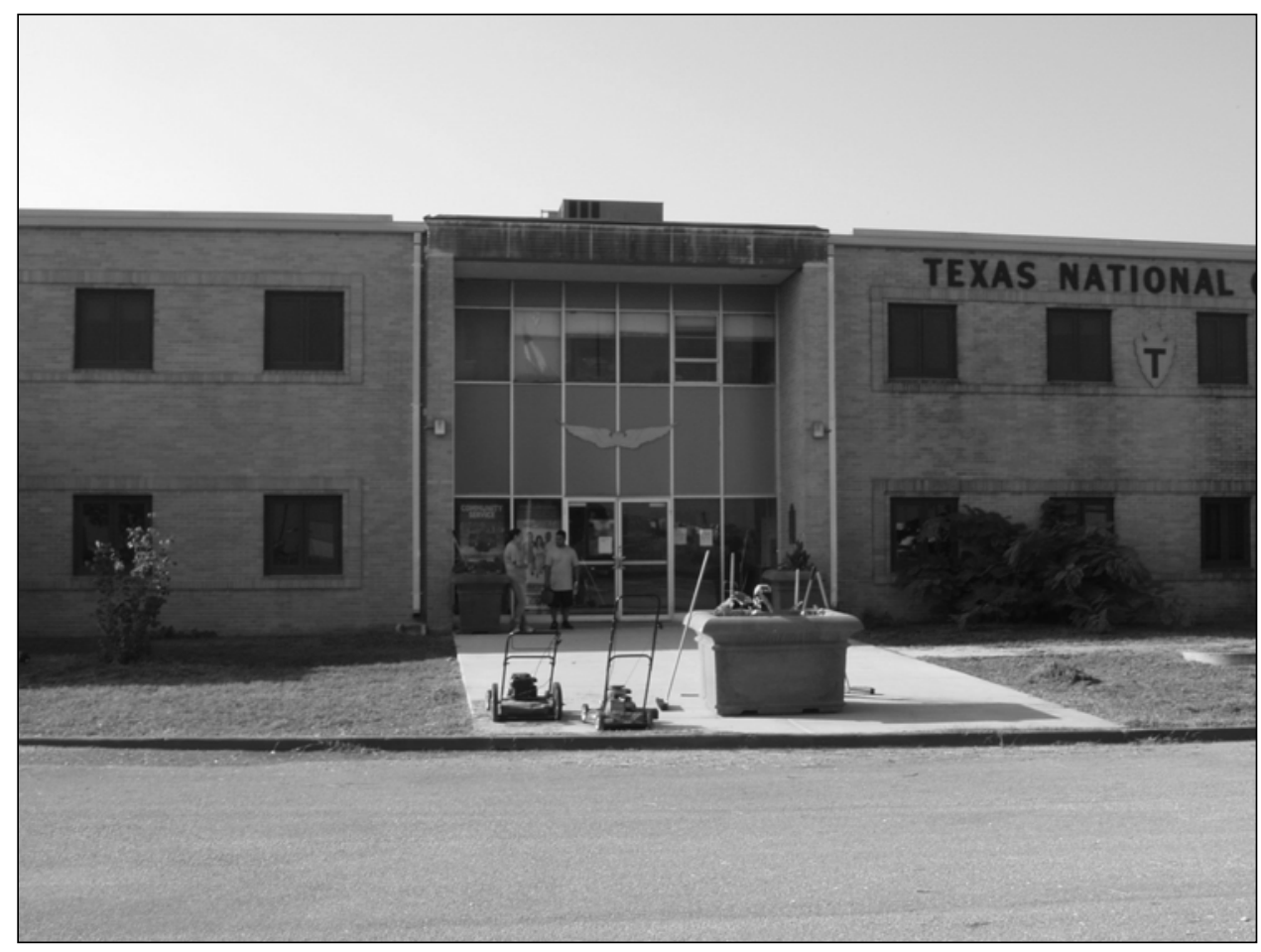

Figure 2-1. Entrance to the Martindale AASF Armory. 


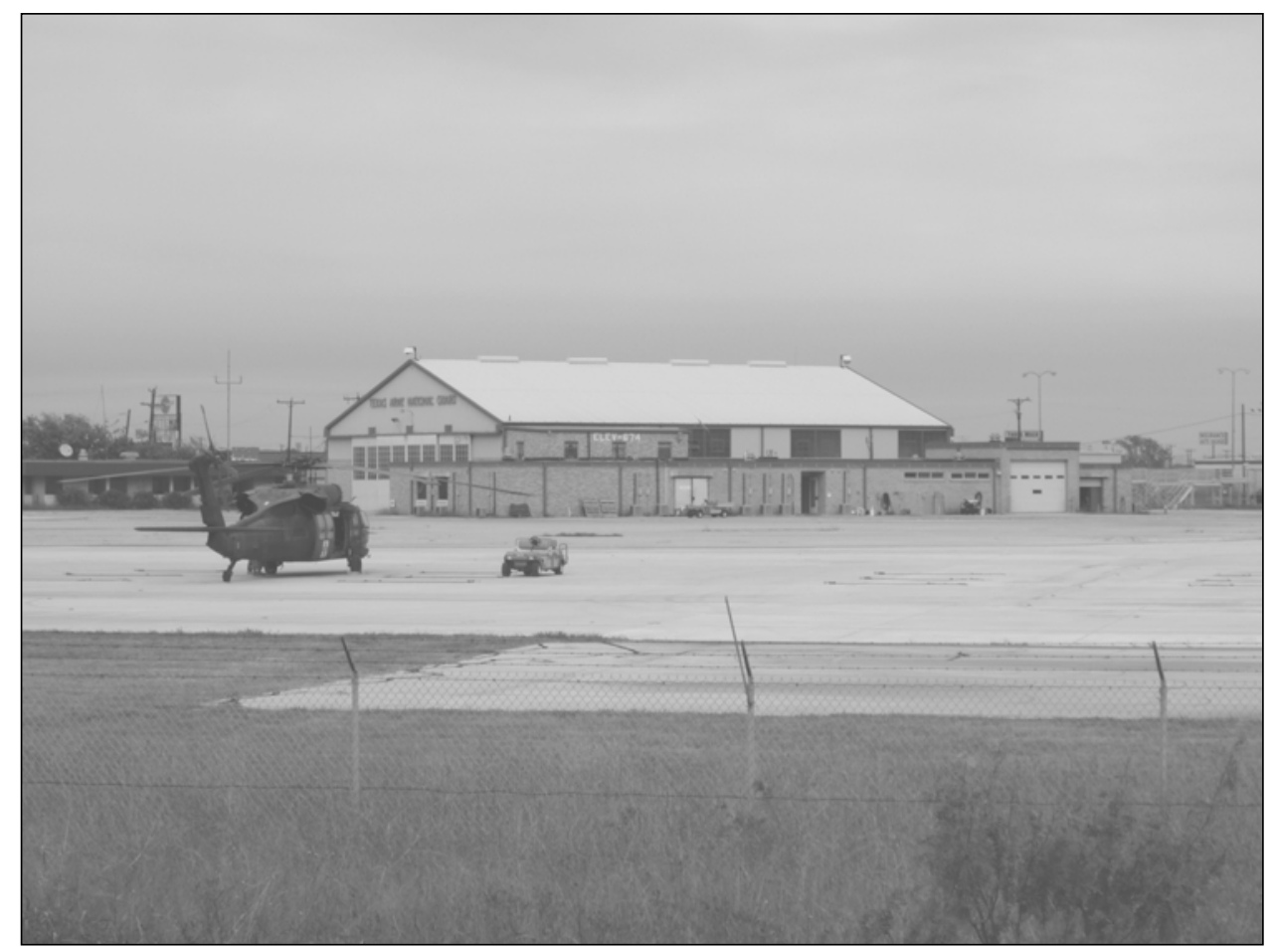

Figure 2-2. The western façade of Building 2, the hangar.

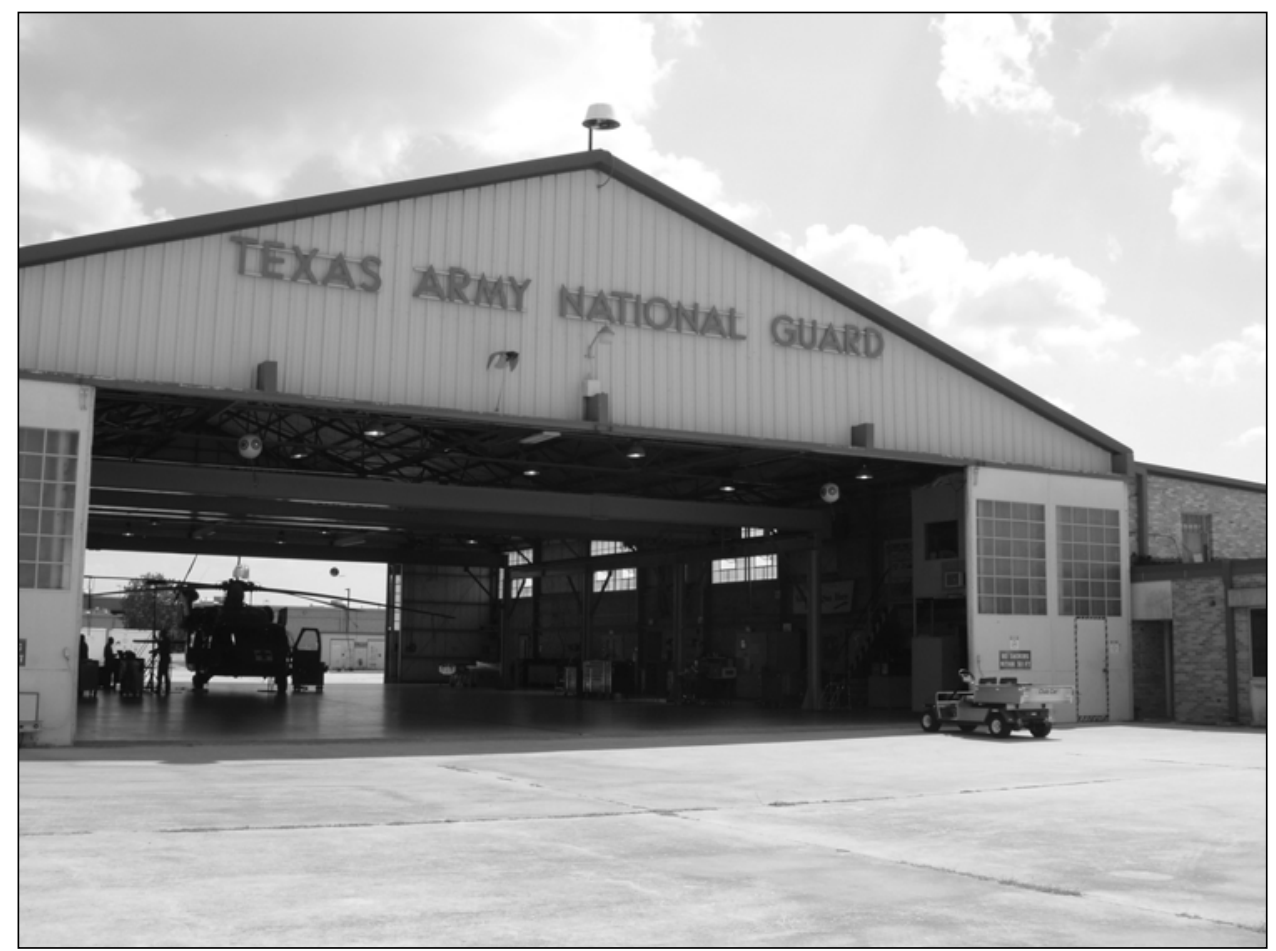

Figure 2-3. The Martindale AASF hangar. 


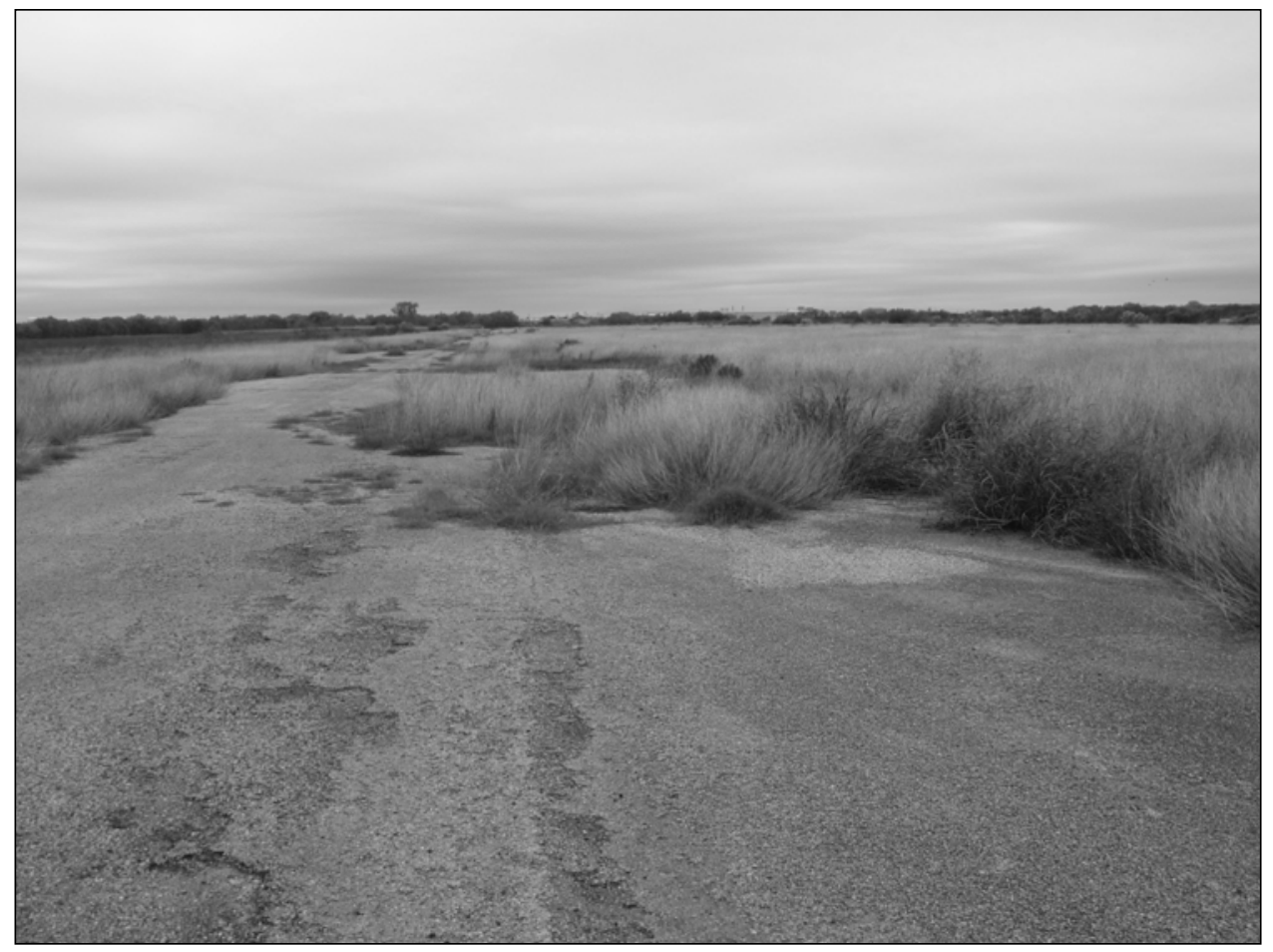

Figure 2-4. An overgrown runway (view to the north).

training, and emergency fire or rescue missions. Presently, a small full time staff maintains the aircraft in addition to serving their monthly and yearly Texas Army National Guard duties. Their primary mission has been to provide emergency support in natural disasters. In recent weeks most of the Martindale units have been called to serve in the war with Iraq (Thompson 2006).

\section{Project Environs}

Martindale AASF is located on the San Antonio East and the Martinez, Texas 7.5-minute USGS quadrangle maps. Elevations in the project area range from 660 to $670 \mathrm{ft}$. AMSL. The facility is located in the Blackland Prairies vegetational area (South Central Texas Regional Water Planning Group 2006). This area supports a diverse assemblage of flora including a variety of oaks (Quercus spp.), pecan (Carya illinoinensis), cedar elm (Ulmus crassifolia), mesquite (Prosopis sp.), buffalograss (Bouteloua dactyloides), Texas grama (Bouteloua rigidiseta), big bluestem (Andropogon gerardii), little bluestem (Schizachyrium scoparium), Indiangrass (Sorghastrum nutans), switchgrass (Panicum virgatum), sideoats grama (Bouteloua curtipendula), hairy grama (Bouteloua hirsuta), tall dropseed (Sporobolus asper), and Texas wintergrass (Stipa leucotricha)(USDA 2007).

The soils in the immediate vicinity of the project area are Houston Black-Houston Association. This association is defined as deep clayey soils over calcareous clay and marl. The AASF is situated on land consisting of approximately 95 percent Houston Black clay, terrace, 0 to 1 percent slopes (HtA) and 5 percent Houston Black clay, terrace, 1 to 3 percent slopes (HtB). This area is characterized by broad, nearly level to undulating uplands overlying calcareous clay and marl of the Taylor and Navarro formations. Overall, the soils are deep, slowly permeable, dark colored and clayey (Taylor et al. 1966).

Climate in this general area is classified as humid subtropical with hot, humid summers and mild, dry winters. Rainfall averages approximately 30 in. a year. The mean annual temperature for the region is $70^{\circ} \mathrm{F}$ (South Central Texas Regional Water Planning Group 2006). 


\section{Culture History}

The project area lies at the intersection of two broad archaeological regions, Central Texas and South Texas. Because archaeological sites with long sequences of stratified deposits are sparse in South Texas, the prehistoric sequence developed for Central Texas is often relied upon to frame the prehistory of South Texas. The following culture history emphasizes Central Texas although reference is made to trends in South Texas. The discussion is based primarily on the chronologies developed by Collins (1995), Johnson and Goode (1994), and Black (1989) for Central Texas, with observations from Hester (1995) for South Texas. Four major time periods define South Central Texas: Paleoindian, Archaic, Late Prehistoric, and Historic. These periods are further divided into sub-periods that are based on particular subsistence strategies and material culture. A brief description of each period follows to illustrate the archaeological potential of the region.

\section{Paleoindian}

The Paleoindian period (11,500-8800 BP) is divided into early and late sub-periods, each characterized by particular projectile point styles and subsistence patterns (Collins 1995). The period begins at the close of the Pleistocene with the earliest evidence of humans in the Central Texas region. Projectile points include lanceolate-shaped, fluted forms such as Clovis, Plainview, and Folsom. These points, hafted onto wooden spears and thrown from atlatls, were used to hunt big game such as mastodon, mammoth and Bison antiquus (Black 1989). Paleoindian artifacts are commonly recovered as isolated finds or from lithic scatters lacking good stratigraphic context including kill, quarry, cache, camp, ritual and burial sites (Collins 1995).

\section{Archaic}

The Archaic period (8800-1200 BP) is marked by an intensification in hunting and gathering of local resources and by a broader array of material culture (Collins 1995). A change in food processing is evident from a widespread increase in hearth, oven and midden features. During this period, large cemeteries were formed indicating an increasing population and the subsequent establishment of territories (Black and McGraw 1985). Collins (1995) and Johnson and Goode (1994) subdivide the Archaic into Early, Middle, and
Late subperiods. These subperiods are distinguished by variances in climate conditions, resource availability, subsistence practices, and diagnostic projectile point styles (Collins 1995; Hester 1995).

\section{Late Prehistoric}

The beginning of the Late Prehistoric period (1200-350 BP) is marked by the appearance of arrow points, indicative of bow and arrow technology, and pottery (Collins 1995). The Late Prehistoric is subdivided into early and late sub-periods termed Austin and Toyah Phases, respectively. Temporal diagnostics including Scallorn and Edwards arrow points define the Austin Phase (1200-650 BP; Prewitt 1981). It appears that the use of burned rock middens may have reached its peak during this phase (Black and Creel 1997). The subsequent Toyah Phase spans 650-350 BP and includes the first occurrence of pottery in South Texas. Characteristic artifacts of this phase include Perdiz and Cliffton arrow points (Black 1986). Material culture associated with the Late Prehistoric period points to increasing complexity in subsistence patterns and to very large prehistoric populations (Black 1989; Collins 1995).

\section{Historic}

The Historic period in South Texas begins with the arrival of Europeans. Although the Historic period theoretically begins in Texas with the shipwreck of the Narvaez expedition along the Texas coast in 1528, the majority of the inhabitants of Texas were Native Americans until the late eighteenth century. From AD 1550 to the late 1600s, European forays into South and Central Texas were infrequent. The first Europeans settled in the region in early AD 1700 (Taylor 1996). The southward incursion of the Comanche and Apache and the northward expansion of Spanish influence led to the displacement of many of the area's indigenous groups. Some Native Americans moved to the protective environment of the various missions that were established in the area in the early eighteenth century. The move to the missions significantly impacted the hunter-gatherer way of life and the material culture. Artifacts from the Historic period reflect European influences and include metal, glass, and ceramics along with pre-Hispanic Goliad wares and lithic arrow points, tools, and gunflints. 


\section{Previous Archaeological Investigations}

A background literature review revealed several archaeological surveys and sites near Martindale AASF. These sites, both prehistoric and historic, are all located along and in the immediate vicinity of Rosillo Creek. Because the project area is within one-half mile of the Rosillo Creek drainage, a desirable locale for prehistoric hunters and gatherers, potential exists for cultural resources. Archaeological sites in close proximity to the project area are 41BX770, 41BX771, 41BX772, 41BX782, 41BX783, 41BX784, 41BX839 and 41BX1460.

In June of 1987, PBS\&J conducted an archaeological survey along Rosillo Creek as part of the Rosillo Creek Development project. This survey documented six sites, 41BX770, 41BX771, 41BX772, 41BX782, 41BX783, and 41BX784. Five were determined to be single component historic sites and one a single component prehistoric site.

Site 41BX770 is a single component site of $325,000 \mathrm{~m}^{2}$ situated on a ridge top east of Rosillo Creek drainage, approximately 1,191 m east of Martindale AASF. Three shovel tests were excavated at the site, all of which lacked cultural material. Materials collected from the surface include prehistoric stone tools, cores, tested gravels, and chipped stone debitage. Stone tools recovered include one non-diagnostic projectile point midsection, one stemmed projectile point base, one projectile point preform, one bifacial gouge, and two thin biface fragments. Further work was not recommended due to poor integrity of the deposits and associated cultural materials resulting from plowing and bioturbation (THC 2006).

Site 41BX771 is a single component site of $960 \mathrm{~m}^{2}$ located on the west side of Rosillo Creek about $181 \mathrm{~m}$ east of Martindale. This is a small farmstead consisting of structures and historic artifacts. Materials collected include glass, whiteware, and various metal objects. Subsurface testing consisted of two shovel tests, both of which were negative. Additional work was recommended to determine the function of the structures and assess NRHP eligibility (THC 2006).

Site 41BX772 is a single component site located on a level upland terrace on the west side of Rosillo Creek roughly $224 \mathrm{~m}$ northeast of Martindale. The site has been identified as the Emil Gembler farm and consists of a mid-sized, woodframed house, three wood-framed outbuildings, an aboveground wooden cistern, several animal pens, and accumulations of historic trash. Subsurface testing consisted of two shovel tests, both of which were culturally sterile. Further research was recommended to assess the site's NRHP eligibility (THC 2006).

Site 41BX782 is a $1,200 \mathrm{~m}^{2}$, single component historic site situated west of Rosillo Creek on the western edge of a broad terrace overlooking the floodplain. It is located approximately $721 \mathrm{~m}$ northeast of Martindale AASF and consists solely of piles of lumber and assorted building materials from a post mid-1930s house and outbuildings. No subsurface testing was conducted at the site. Because of the age of the structures, the site was determined to be ineligible for the NRHP (THC 2006).

Site 41BX783 consists of buildings and structures identified as the Adolph Hild Farm. Surface inspection revealed a house foundation, a well/cistern, and a stock tank with an associated pump house. The site is situated on the southwest side of a gently sloping upland terrace overlooking Rosillo Creek. 41BX783 is roughly $1,541 \mathrm{~m}$ northeast of Martindale. No subsurface testing was conducted. Further research was recommended to determine the site's NRHP eligibility status (THC 2006).

Site 41BX784 is a single component historic site identified as the Richard Hild Farm. The site is located on a gently sloping terrace west of Rosillo Creek, approximately 1,391 m northeast of Martindale AASF. No subsurface testing was conducted and no artifacts were collected. A visual inspection of the site revealed two cisterns, two water troughs, a tank and associated wood-frame pump house, three concrete slabs, seven rubble piles representing house sites, and five associated structures. Because the site is typical of the area's farm settlement period, it may be eligible for the NRHP. Further research was recommended (THC 2006).

In 1990, M. Khonitz with the University of Texas at San Antonio Center for Archaeological Research recorded site 41BX839, situated approximately $667 \mathrm{~m}$ southwest of the project area. It was concluded that the site was a single component prehistoric lithic scatter. No subsurface testing was conducted. Materials collected include a Tortugas point, a Pedernales point, Guadalupe tools, and debitage (Khonitz 1990; Barile 2002).

In 1994, a pedestrian survey sponsored by Williams Communications was conducted along the west side of Rosillo Creek. During this survey sites 41BX772 and 41BX782 were revisited. Site 41BX782 was reclassified as a 
multi-component site consisting of historic debris and prehistoric lithic debitage. No temporally diagnostic artifacts were recovered. No additional information could be located for this revisit of 41BX772 (Barile 2002).

In 1999, Burns and McDonnell conducted an archaeological survey for a Texas Department of Transportation (TxDOT) impact evaluation. This survey revisited sites 41BX839 and 41BX782. The 1987 survey of 41BX782 by PBS\&J concluded that the site was a single component historic homestead, whereas the 1994 Williams Communications survey concluded the site was multi-component. The 1999 revisit also revealed a prehistoric component consisting of a light lithic scatter. No recommendations on eligibility were documented on the site form (THC 2006). Site 41BX839 is a prehistoric lithic scatter consisting of a core fragment, a flake and a specimen of unworked, petrified wood. The site is located on the west descending bank of Rosillo Creek approximately $667 \mathrm{~m}$ southwest of the project area. No subsurface testing was conducted. The portion of the site within the TxDOT right-of-way (ROW) was determined to be completely destroyed, thus having no research value. However, the site was not investigated beyond the ROW (THC 2006).

In 2001, SWCA, Inc. Environmental Consultants conducted an archaeological survey on Segment III of the San Antonio Water System Aquifer Storage and Recovery Pipeline Project (Barile 2002). The survey involved the ROW associated with the proposed pipelines. Two sites were revisited, 41BX782 and 41BX839, and one new site recorded, 41BX1460. The revisit of 41BX782 noted a high quantity of historic and prehistoric artifacts scattered on the surface. Two shovel tests were excavated with similar artifacts recovered. No temporal diagnostics were found. Site 41BX782 was determined to be ineligible to the NRHP. Eight shovel tests were excavated along the ROW to determine impacts to 41BX839. Artifacts recovered include lithic debitage and one possible bifacially worked cobble. The site was determined to be potentially eligible for the NRHP. 41BX1460 is a single component site consisting of the remains of a historic structure dated from 1890 to 1920. A light scatter of historic artifacts was noted surrounding the structure. The site is located on a plateau on the west side of Rosillo Creek approximately $1,053 \mathrm{~m}$ southeast of Martindale AASF. The one shovel test excavated contained no cultural material. Because the structure has poor physical integrity and few associated historic artifacts, it was not recommended as significant or eligible to the NRHP (Barile 2002). 


\section{Chapter 3: Field and Laboratory Methods}

As part of the archaeological services provided to the Texas Military Forces, and in accordance with the Texas Historical Commission guidelines, the Center for Archaeological Research was contracted to conduct the following fieldwork: (1) complete a 100 percent pedestrian survey accompanied by shovel testing of the 121 acres of open fields surrounding the airfield buildings and runways; (2) GPS all shovel tests; and (3) identify, delineate and record GPS data for the boundaries of any sites recorded during the survey. This chapter presents the field and laboratory methods used during the archaeological investigations of Martindale AASF.

\section{Field Methods}

The total area of the Martindale AASF is 216 acres $\left(874,114 \mathrm{~m}^{2}\right)$. The survey area (area not containing facilities buildings and hard surfaces) is 121 acres $\left(489,400 \mathrm{~m}^{2}\right.$; see Figure 1-2). The archaeological investigation consisted of a 100 percent pedestrian survey and shovel testing. The CAR field crew traversed the project area along transects spaced $30 \mathrm{~m}$ apart. Based on the width of the facility, $916 \mathrm{~m}$ (1 transect/30 m), 30 transects were surveyed. Aerial photographs and hand-held compasses were used to orient crewmembers. Surface artifacts were noted and recorded with Trimble Geo XT GPS units.

Based on the survey area, to fulfill the THC minimum survey standards it was required that a minimum of 41 shovel tests (STs) be excavated within the target area, at a density of one shovel test per three acres. Shovel test locations were determined through a random selection process. Initially, a 60-x-60-m grid was created and overlain on the aerial photo of the base. The southern and western sides of the grid were positioned such that they aligned with the southern and western boundaries of the base. This resulted in the identification of 255 potential shovel test locations in a grid roughly $960 \mathrm{~m}$ (north-south) by $840 \mathrm{~m}$ (east-west). From that data set a sample of 39 percent was selected using random criteria available in SPSS 14.1. This resulted in 100 possible locations. Those locations that fell within the runways or developed facilities at the base, as well as those locations that fell outside of the base, were eliminated. The remaining sample consisted of 55 locations. UTM coordinates for these 55 locations were determined, and uploaded into Trimble Geo XT GPS units. Shovel tests were located in the field using the GPS map feature. Eight additional shovel tests were excavated due to positive tests and surface artifacts near the eastern boundary of the project area. Each of two positive shovel tests was ringed by four additional tests in the cardinal directions to attempt to delineate the boundary of the cultural material concentration. Overall, the intensive pedestrian survey resulted in the hand-excavation of 63 shovel tests (Figure 3-1).

Shovel tests were $30 \mathrm{~cm}$ in diameter, and when not prevented by obstacles (e.g., large roots, cobbles), extended to a depth of $60 \mathrm{~cm}$. Because the majority of the survey area has been plowed, the first $20 \mathrm{~cm}$ of each test in the plowed areas were excavated as one level. The remaining levels were excavated in 10-cm increments, and all soil from each level was screened through $1 / 4$-in. hardware cloth. All encountered artifacts were recovered by appropriate provenience and returned to the CAR laboratory for processing, analysis, and curation. A standardized shovel test form was completed for each shovel test, even if no artifacts were recovered. Data collected from each shovel test included the final excavation depth, a tally of all materials recovered from each $10-\mathrm{cm}$ level, and a brief soil description (texture, consistency, Munsell color, inclusions). The location of every shovel test was identified through the use of Trimble Geo XT GPS units. Shovel test locations were sketched onto topographic maps or aerial photographs as a backup to GPS provenience information. Any additional observations considered pertinent were included as comments on the standard shovel test excavation form.

For the purposes of this survey, newly encountered archaeological sites were defined as locations containing a certain number of cultural materials or features that are at least 50 years old within a given area. For the purpose of this project, the definition of a site was as follows: (1) five or more surface artifacts within a 15 -m radius $\left(\right.$ ca. $706.9 \mathrm{~m}^{2}$ ); or (2) a single cultural feature, such as a hearth, observed on the surface or exposed in shovel testing; or (3) a positive shovel test containing at least three artifacts within a given $10-\mathrm{cm}$ level; or (4) a positive shovel test containing at least five total artifacts; or (5) two positive shovel tests located within $30 \mathrm{~m}$ of each other. 


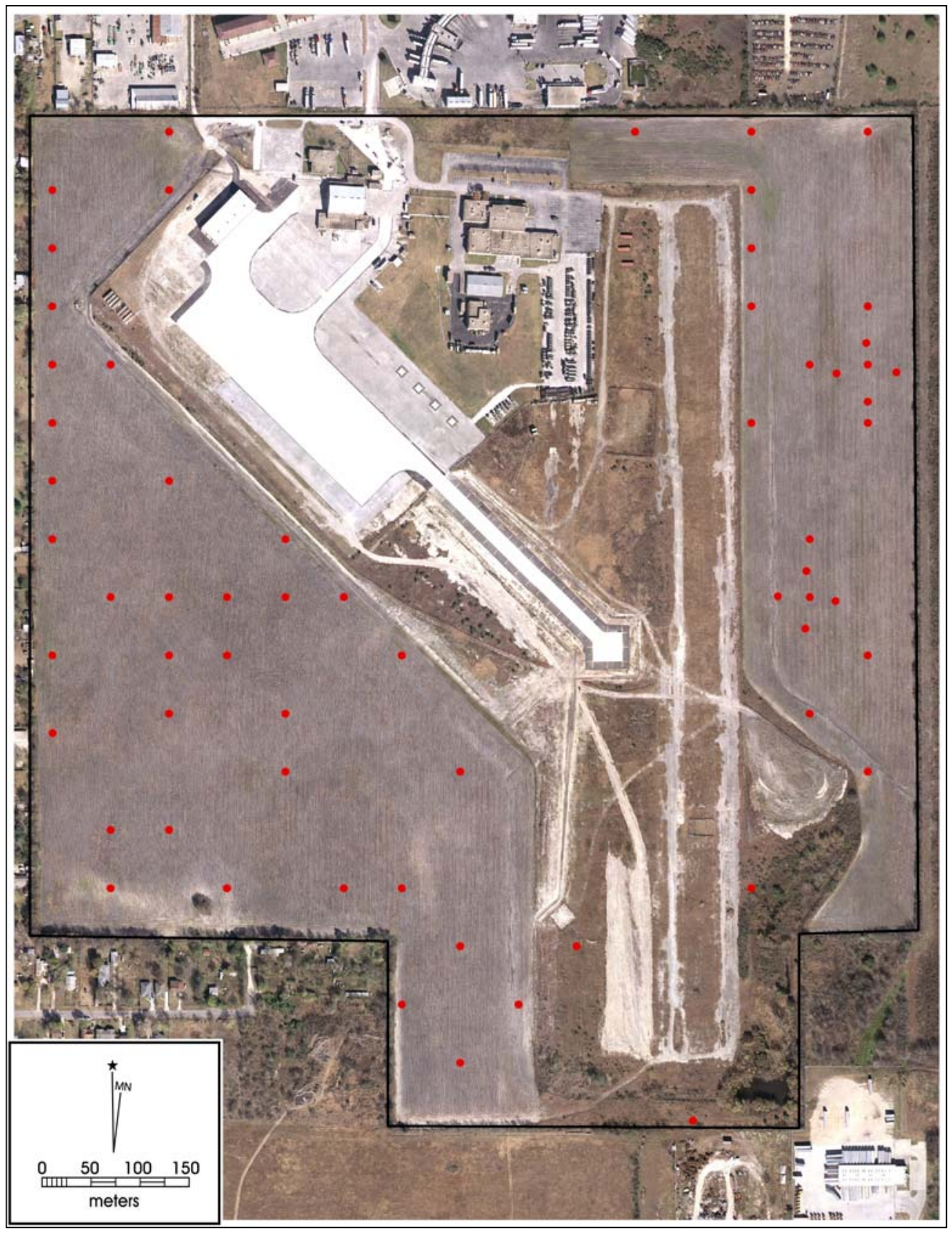

Figure 3-1. Location of shovel tests at Martindale AASF. 
One site, 41BX1694, was encountered on the Martindale AASF based on the above requirements. Additional shovel tests were excavated at close intervals to define the extent of the distribution. The site boundary was plotted on an aerial photograph and a topographic quadrangle map using location data collected with a GPS unit. A Texas Archeological Site Data Form was prepared for 41BX1694.

Artifacts encountered that did not meet the minimum requirements for a site, were treated as isolated finds. These artifacts were recorded with a GPS unit and their locations were plotted on the maps and aerials.

\section{Archaeological Laboratory Methods}

Cultural materials and records obtained and/or generated during the project were prepared in accordance with federal regulation 36 CFR Part 79, and THC requirements for State Held-in-Trust collections. Additionally, the materials were curated in accordance with current guidelines of the Texas Archeological Research Laboratory (TARL). Artifacts processed in the CAR laboratory were washed, air-dried and stored in 4-mm zip-locking, archival-quality bags. Materials needing extra support were double-bagged. Acidfree labels were placed in all artifact bags. Each label contained provenience information and a corresponding lot number written in archival ink, with pencil or laser printed. Tools were labeled with permanent ink over a clear coat of acrylic and covered by another acrylic coat. Artifacts were separated by class and stored in acid-free boxes. Digital photographs were printed on acid-free paper and labeled with archivally appropriate materials and placed in archival-quality sleeves. All field forms were completed with pencil. Modern trash recovered from the survey was discarded, and each discard documented in the artifact catalog. Upon completion of the project collected materials were housed at TARL. 



\section{Chapter 4: Survey Results}

The survey of Martindale AASF was completed between October 24 and November 3, 2006 under the direction of Project Archaeologist Cynthia Munoz. The fieldwork consisted of a 100 percent pedestrian survey of 121 acres accompanied by shovel testing ( $n=63$; see Figure 3-1). The placement of the shovel tests $(n=55)$ was based on random sampling along 30 transects spaced $30 \mathrm{~m}$ apart. The additional eight shovel tests were excavated to establish the site boundary for 41BX1694. The pedestrian survey and shovel testing of Martindale AASF revealed sparse numbers of historic artifacts and, along the eastern side of the project area, a light distribution of prehistoric cultural material. This chapter discusses the results of the pedestrian survey of the facility.

\section{Shovel Tests}

Sixty-three shovel tests were excavated during the survey of Martindale AASF (Figure 3-1). All but two of the shovel tests were excavated to $60 \mathrm{~cm}$ below surface (cmbs). Shovel
Test 37 was located on overgrown runway pavement and ST 44 contained solid rock at $19 \mathrm{cmbs}$ (Figure 4-1). The soils from all but five of the tests were fairly homogenous only varying slightly and consisted of approximately $23 \mathrm{~cm}$ of soft, plowed, silty clay overlying very dark brown, hard to very hard clay. The sediment contained low occurrences of small pebbles throughout the $60 \mathrm{~cm}$. Two shovel tests (STs 59 and 61) varied in that the clay, from approximately 20 to $60 \mathrm{~cm}$ was very moist with zero to very few inclusions. These tests fall along a drainage that meanders through the eastern side of the project area (Figure 4-2). Three tests (STs 39, 40, and 50) contained a sandy, gravelly fill material (Figure 4-3). This portion of the project area has been artificially altered into a drainage basin. The area consists of berms and drainage ditches leading to a manmade pond (Figures 4-4 and 4-5).

Initially, 55 shovel tests were excavated followed by the placement of eight additional tests. Of the 63 shovel tests, 13 percent were positive $(n=8)$. Eight percent of the tests $(n=5)$

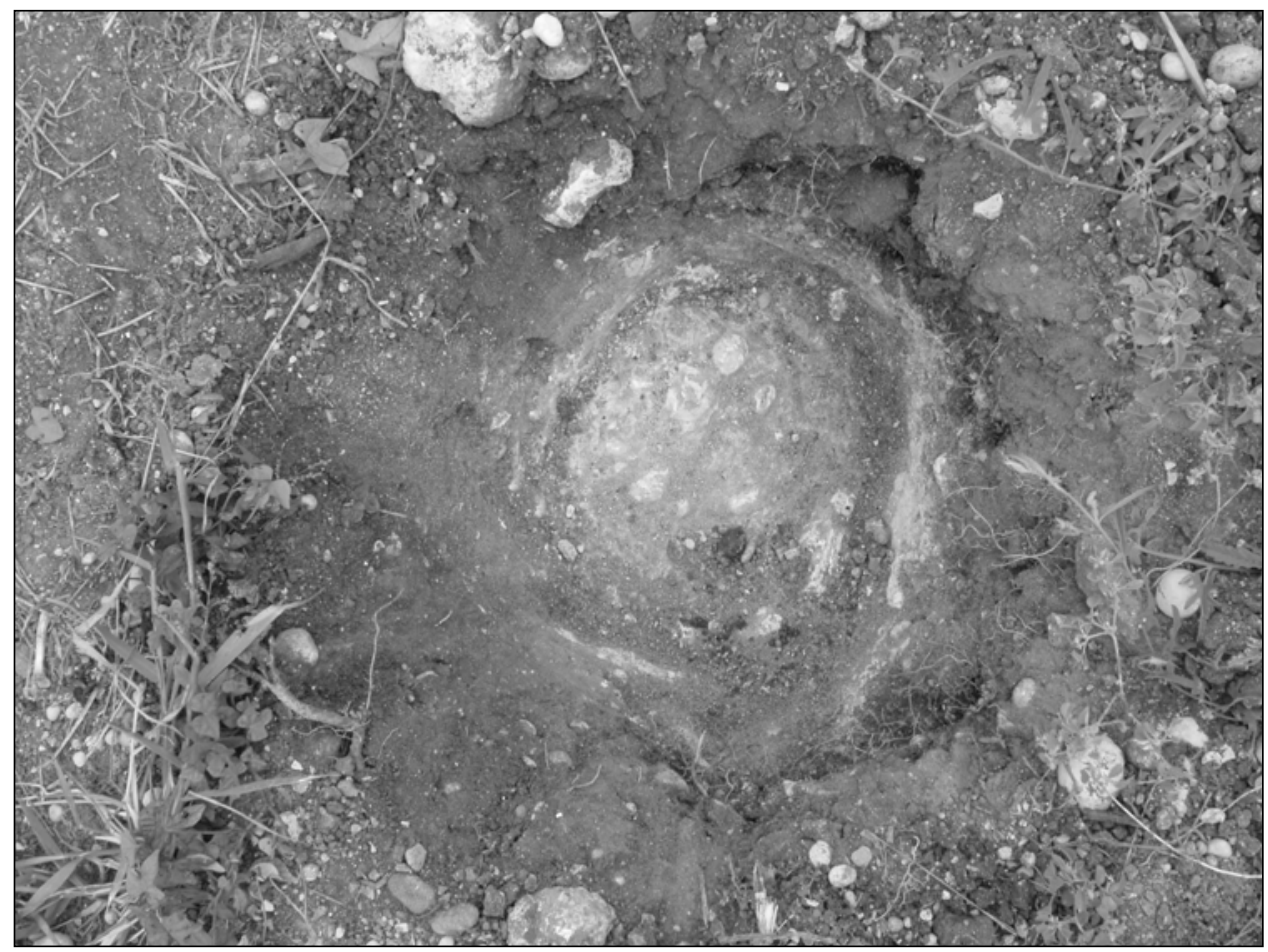

Figure 4-1. Termination of Shovel Test 44 at $19 \mathrm{~cm}$ below surface. 


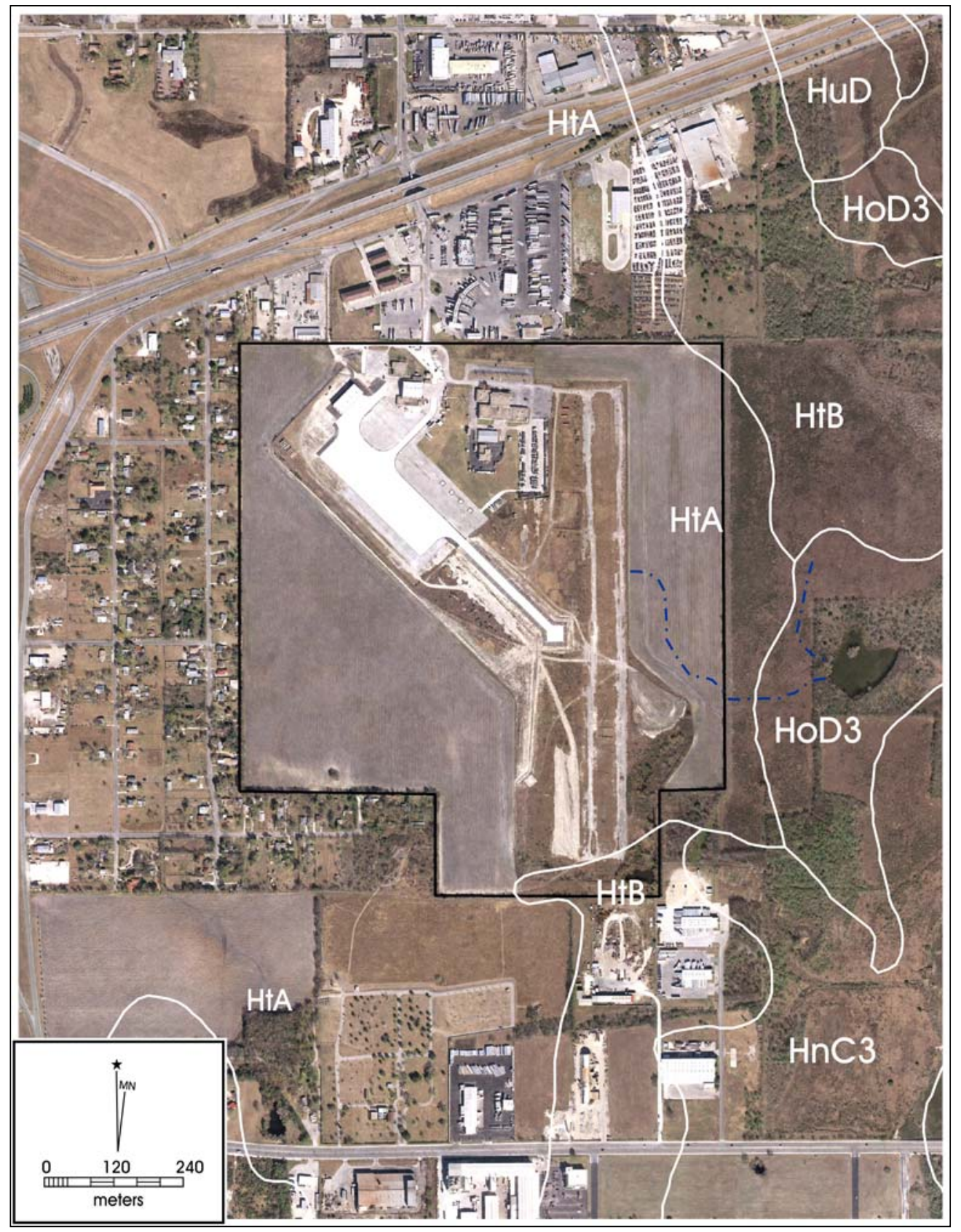

Figure 4-2. Soil map of Martindale AASF including drainage on the eastern side of the project area. 


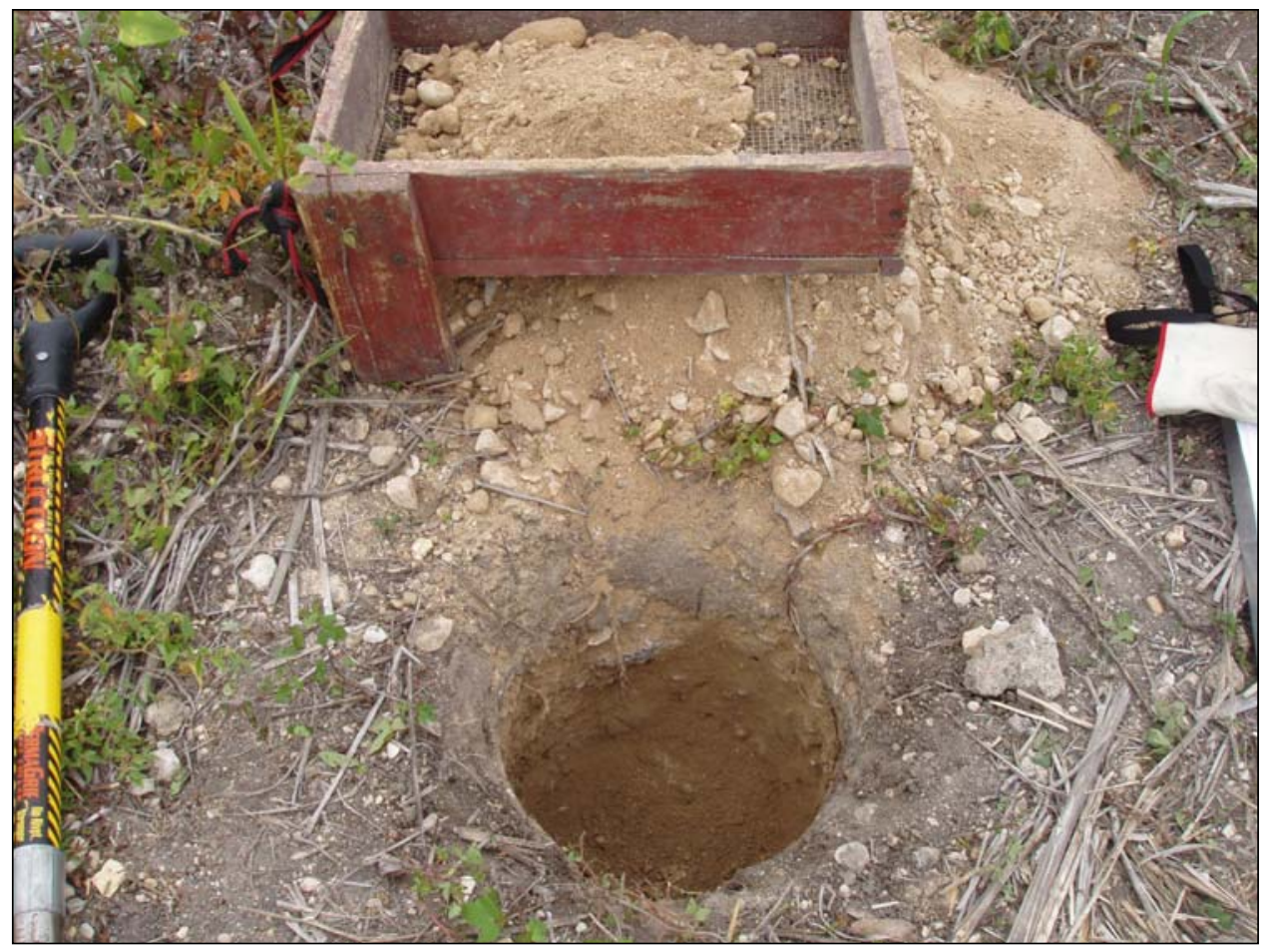

Figure 4-3. Shovel Test 50 (note sandy fill).

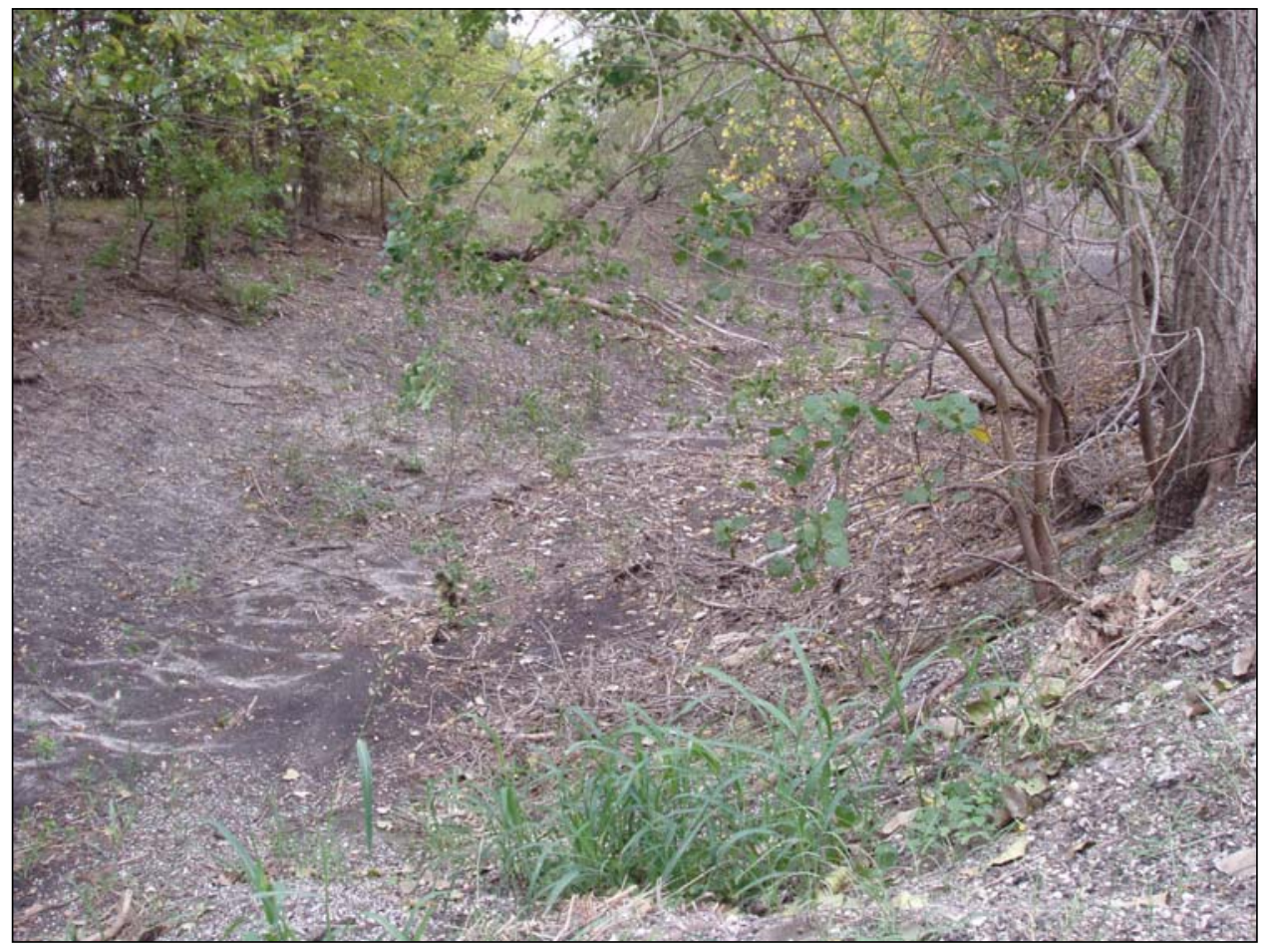

Figure 4-4. Artificial drainage leading to basin on the southeastern edge of the project area. 


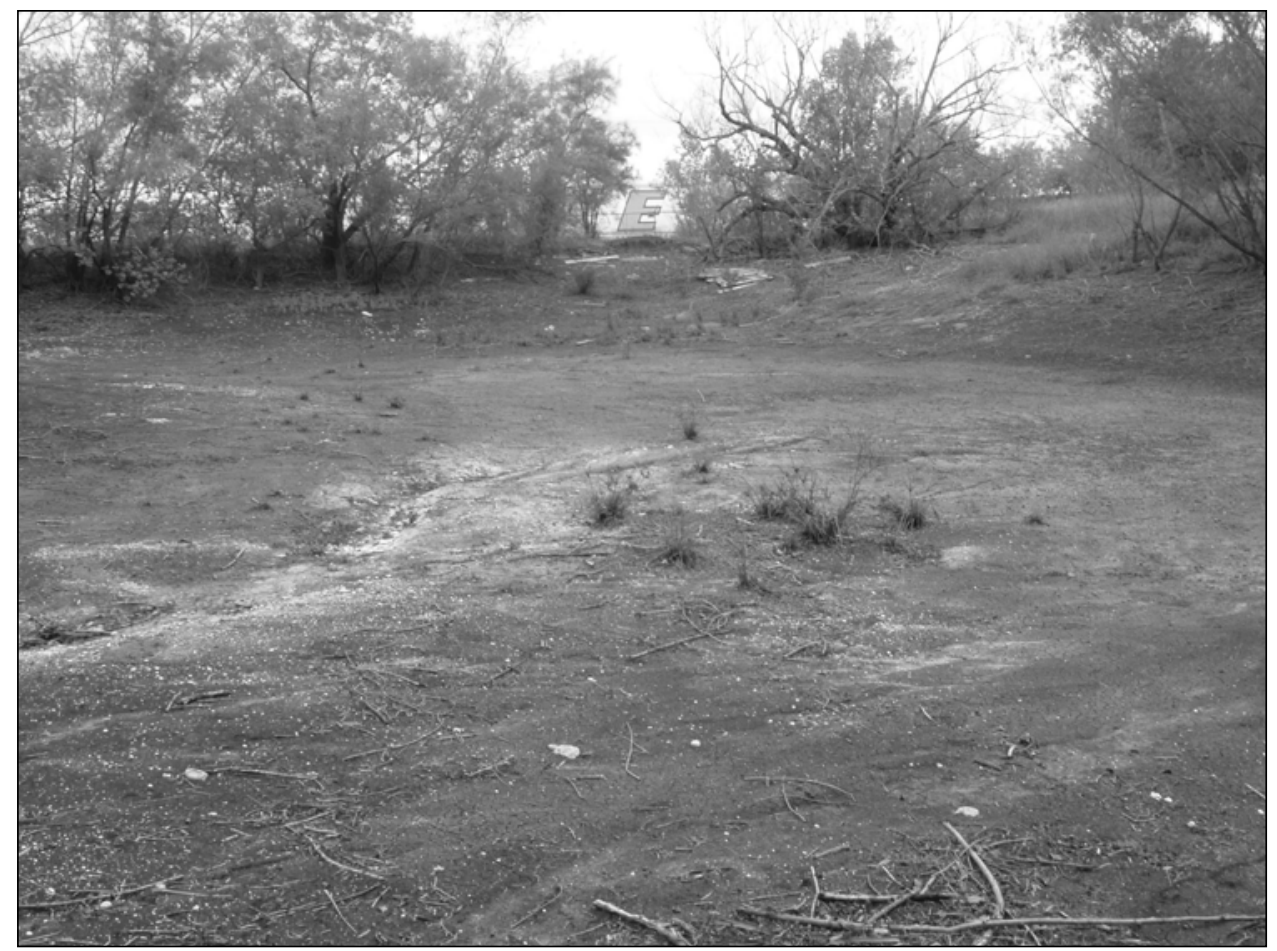

Figure 4-5. Artificial drainage basin on the southeastern edge of the project area.

contained historic artifacts and 5 percent $(n=3)$ contained prehistoric artifacts (Figure 4-6). As discussed in the Field Methods section (Chapter 3), the shovel tests were excavated in five levels with the top $20 \mathrm{~cm}$ screened as Level 1 and the remaining levels removed in $10-\mathrm{cm}$ increments. Nine artifacts were recovered from the shovel test excavations, 56 percent $(n=5)$ from Level 1, 22 percent $(n=2)$ from Level 2, 11 percent $(n=1)$ from Level 3, and 11 percent $(n=1)$ from Level 5. Of the nine artifacts, 67 percent $(n=6)$ were historic (Table 4-1). The eight positive shovel tests and resultant artifacts are discussed below.

\section{Shovel Tests Containing Historic Artifacts}

Shovel Tests 14, 21, 30, 55, and 58 all contained historic artifacts (Figure 4-6; Table 4-1). Shovel Test 14 contained one cut square nail in Level $1(0-20 \mathrm{cmbs})$. Cut nails were made prior to 1850 . The remaining shovel tests contained modern trash including clear glass, brown glass, tile, asbestos tile, and a cartridge casing. The asbestos tile was uncovered in Level 5 (50-60 cmbs) of Shovel Test 21 pointing to disturbance most likely from a combination of plowing and bioturbation.

\section{Shovel Tests Containing Prehistoric Artifacts}

Three shovel tests (STs 47, 53, and 57) contained prehistoric artifacts (Figure 4-6). A core was recovered in Level 3 (30-40 cmbs) of Shovel Test 47, a tested cobble in Level 2 (20-30 cmbs) of Shovel Test 53, and a bifacially retouched tool (Figure 4-7[a]) was recovered in Level $1(0-20 \mathrm{cmbs})$ of Shovel Test 57. This tool measures $60.22 \mathrm{~mm}$ (maximum length) by $51.77 \mathrm{~mm}$ (width) by $27.34 \mathrm{~mm}$ (thickness) and has an edge angle of 86 degrees. The edge angle was computed as an average of three measurements. The tool contains cortex on all unworked surfaces and is distally beveled. Based on its light weight (105 g) and morphological characteristics, this tool may have been used as a wedge.

\section{Surface Finds}

As part of the survey, 30 transects, each $30 \mathrm{~m}$ apart, were walked in a north-south orientation. This survey resulted in the recording of several isolated finds on the eastern side of the project area (Table 4-2; Figure 4-8 ). One bifacial core (Figure 4-7[b]), two specimens of debitage, small scatters of burned rock, one mess kit (Figure 4-9), and one piece of farm 


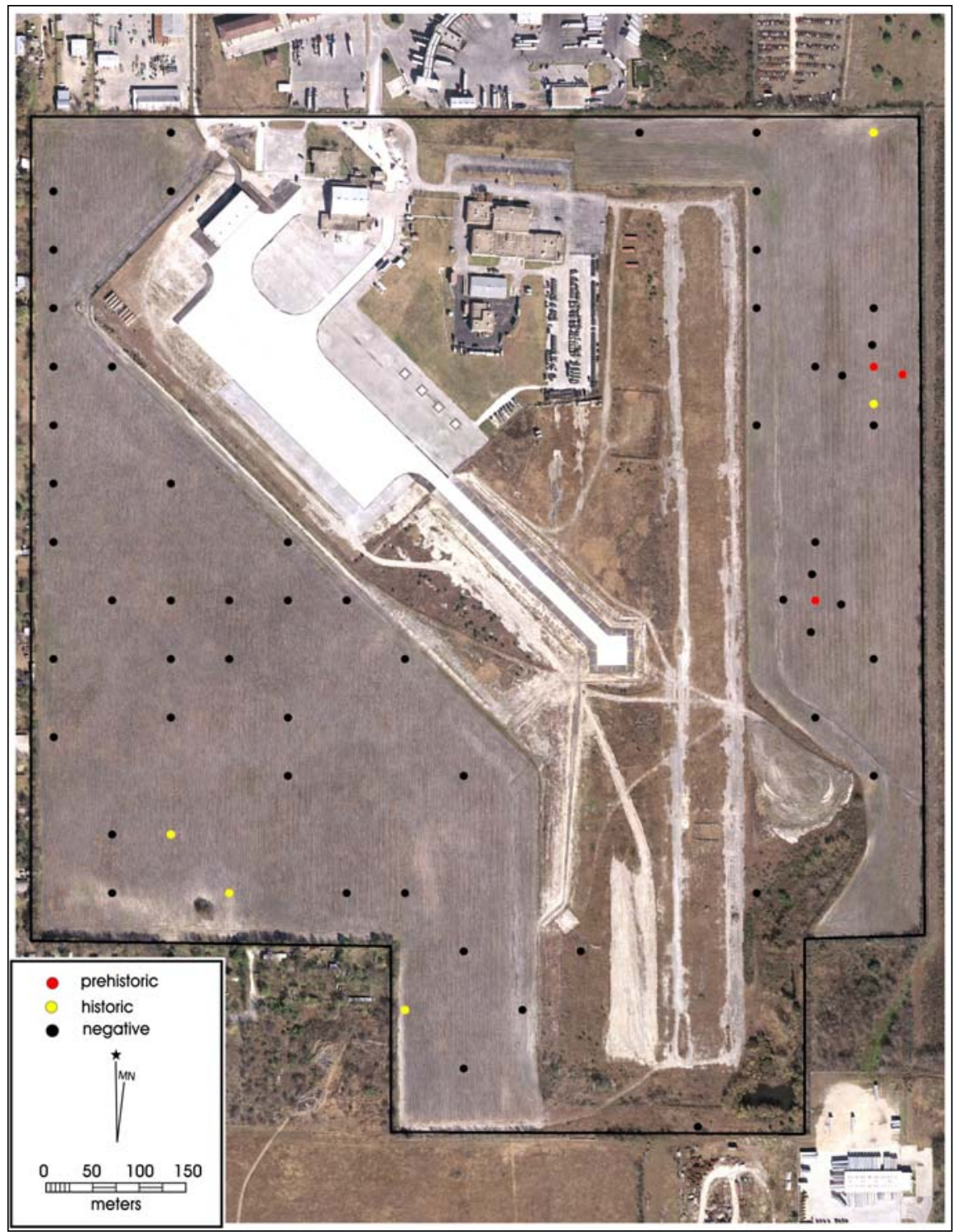

Figure 4-6. Location of shovel tests indicating positive for historic (yellow) and prehistoric (red) finds.

Table 4-1. Shovel Test Results

\begin{tabular}{|c|c|c|c|c|c|c|c|c|}
\hline Provenience & Level & Tool & Core & Tested Cobble & Cut Nail & Glass & Tile & Cartridge Casing \\
\hline ST 14 & 1 & & & & 1 & & & \\
\hline ST 30 & 1 & & & & & 1 & & \\
\hline ST 55 & 1 & & & & & & 1 & \\
\hline ST 57 & 1 & 1 & & & & & & \\
\hline ST 58 & 1 & & & & & & & \\
\hline ST 53 & 2 & & & 1 & & & & \\
\hline ST 55 & 2 & & & & & 1 & & \\
\hline ST 47 & 3 & & 1 & & & & & \\
\hline ST 21 & 5 & & & & & & 1 & \\
\hline
\end{tabular}



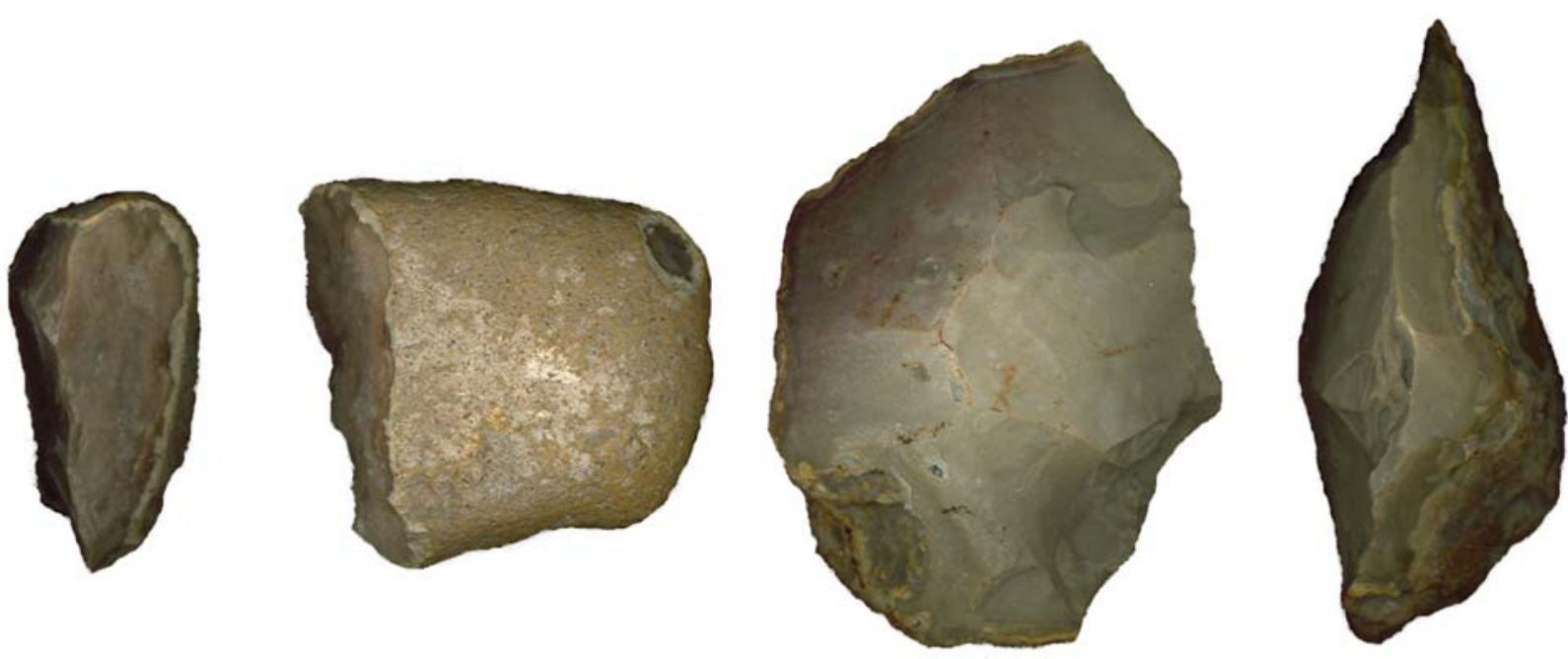

$$
\begin{array}{lll}
0 & 1 & 2
\end{array}
$$

b

Figure 4-7. Artifacts encountered during survey: (a) bifacially retouched tool; (b) bifacial core.

machinery were observed. The mess kit is constructed of tin plated steel. Mess kits of this type were used from World War II through the Vietnam War.

\section{Site 41BX1694}

During the survey of Martindale AASF one new archaeological site was recorded (Figure 4-10). Site 41BX1694 is located along the northeastern boundary of the facility in a plowed open field (Figure 4-11). Based on previously discussed definitions of a site, item five specifies that two positive shovel tests located within $30 \mathrm{~m}$ of each other comprise a site. Shovel Tests 53 and 57 both tested positive for prehistoric artifacts, yielding a tested cobble and a bifacially retouched tool, respectively. Additionally, a surface scatter of burned rock is located $2 \mathrm{~m}$ south of ST 53, an isolated surface specimen of debitage is located $36 \mathrm{~m}$ southwest and a surface scatter of burned rock is located $37 \mathrm{~m}$ southwest of the shovel test. All of the artifacts were encountered in the top $30 \mathrm{~cm}$ of sediments. Large cobbles (140 mm in length) are scattered across the surface of this portion of the project area indicating an availability of lithic material for tool manufacture. Site 41BX1694 is approximately $2364 \mathrm{~m}^{2}$ and was mapped with a GPS unit. Due to the disturbed nature of the top $30 \mathrm{~cm}$ of the project area from bioturbation, rodent activity and soil tilling and to the low density of cultural remains the site appears to retain minimal research potential.

Table 4-2. Isolated Surface Finds

\begin{tabular}{|l|c|c|c|c|}
\hline \multicolumn{1}{|c|}{ Surface Provenience } & Burned Rock & Core & Debitage & Metal \\
\hline Near ST 53 & 2 & & & \\
\hline Near ST 55 & & & & 1 \\
\hline $5 \mathrm{~m}$ S of ST 59 & & & 1 & \\
\hline $5 \mathrm{~m}$ SW of ST 59 & & & & 1 \\
\hline $10 \mathrm{~m}$ S of ST 59 & & & & \\
\hline Adjacent to ST 60 & & & & \\
\hline Near E boundary & & & 1 & \\
\hline
\end{tabular}




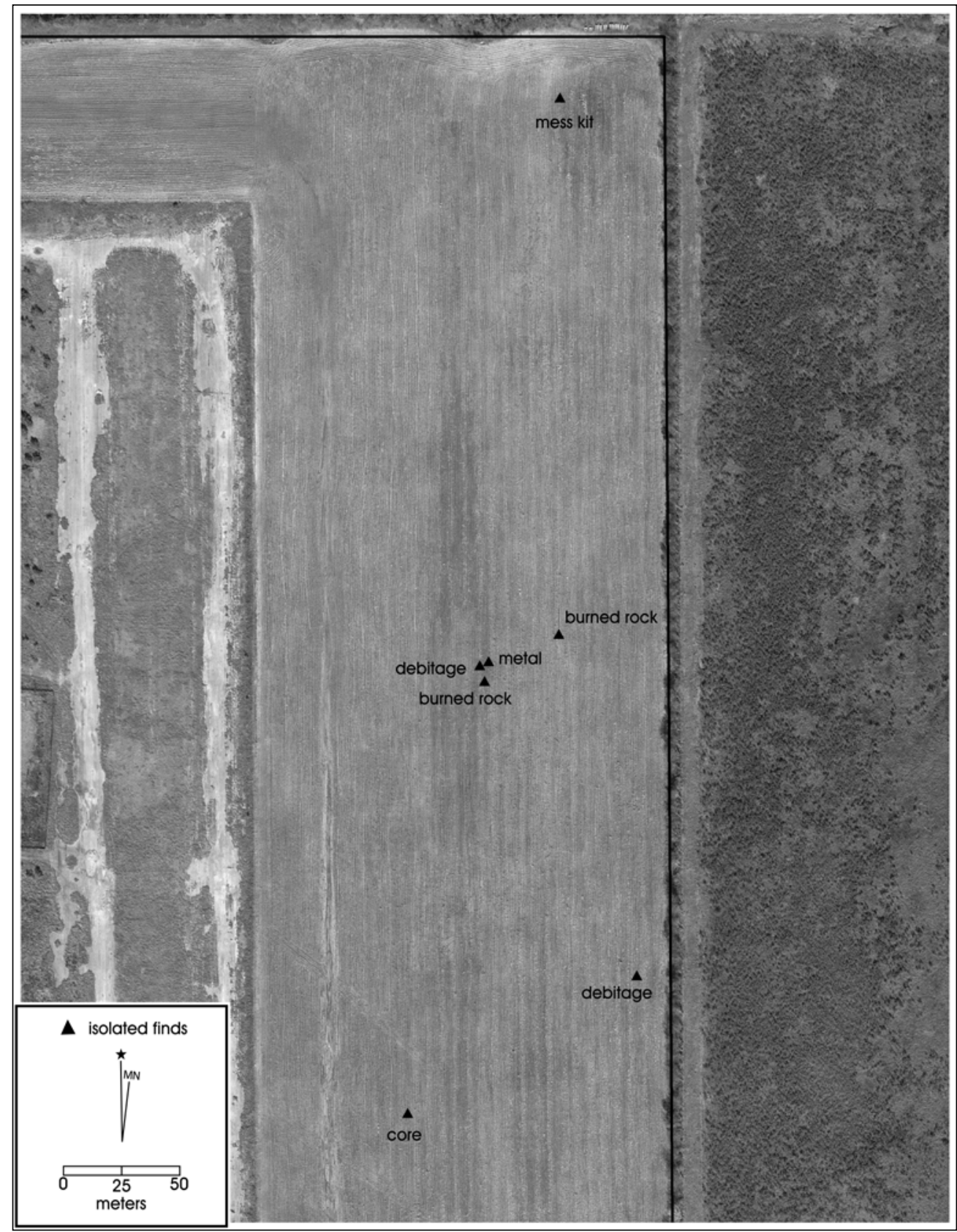

Figure 4-8. Location of isolated finds along the eastern edge of the project area. 


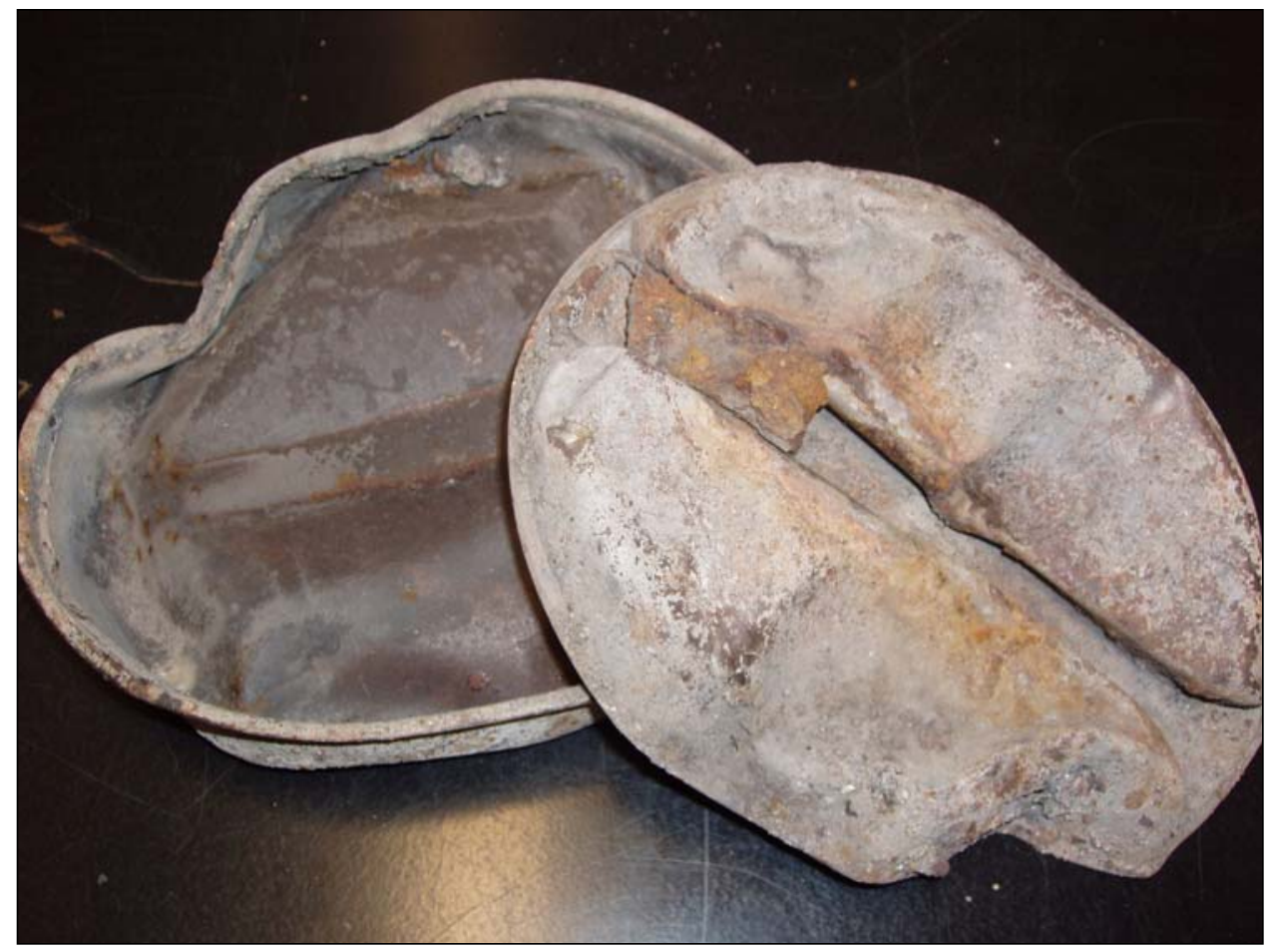

Figure 4-9. Tin plated steel mess kit.

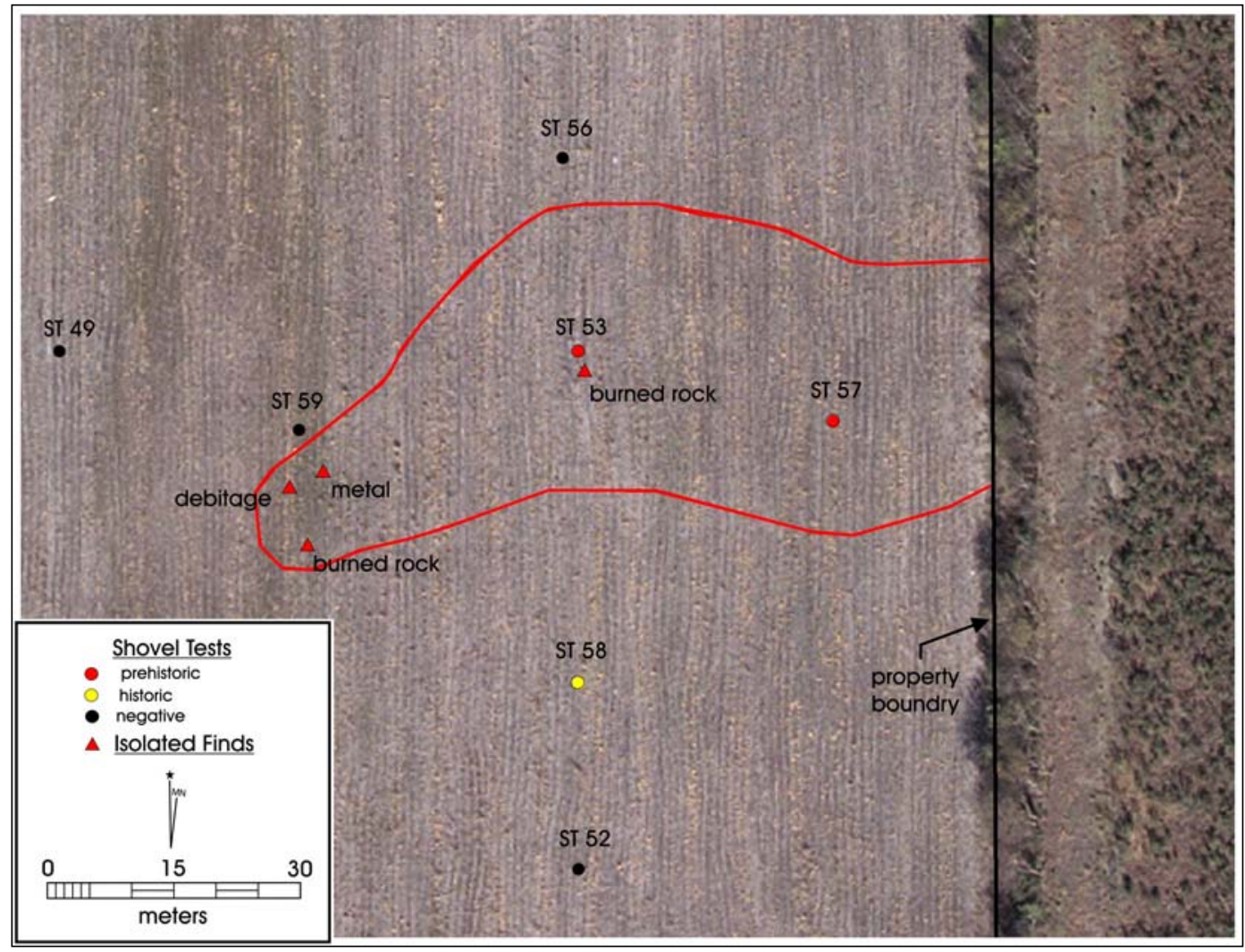

Figure 4-10. Site map of 41BX1694. 


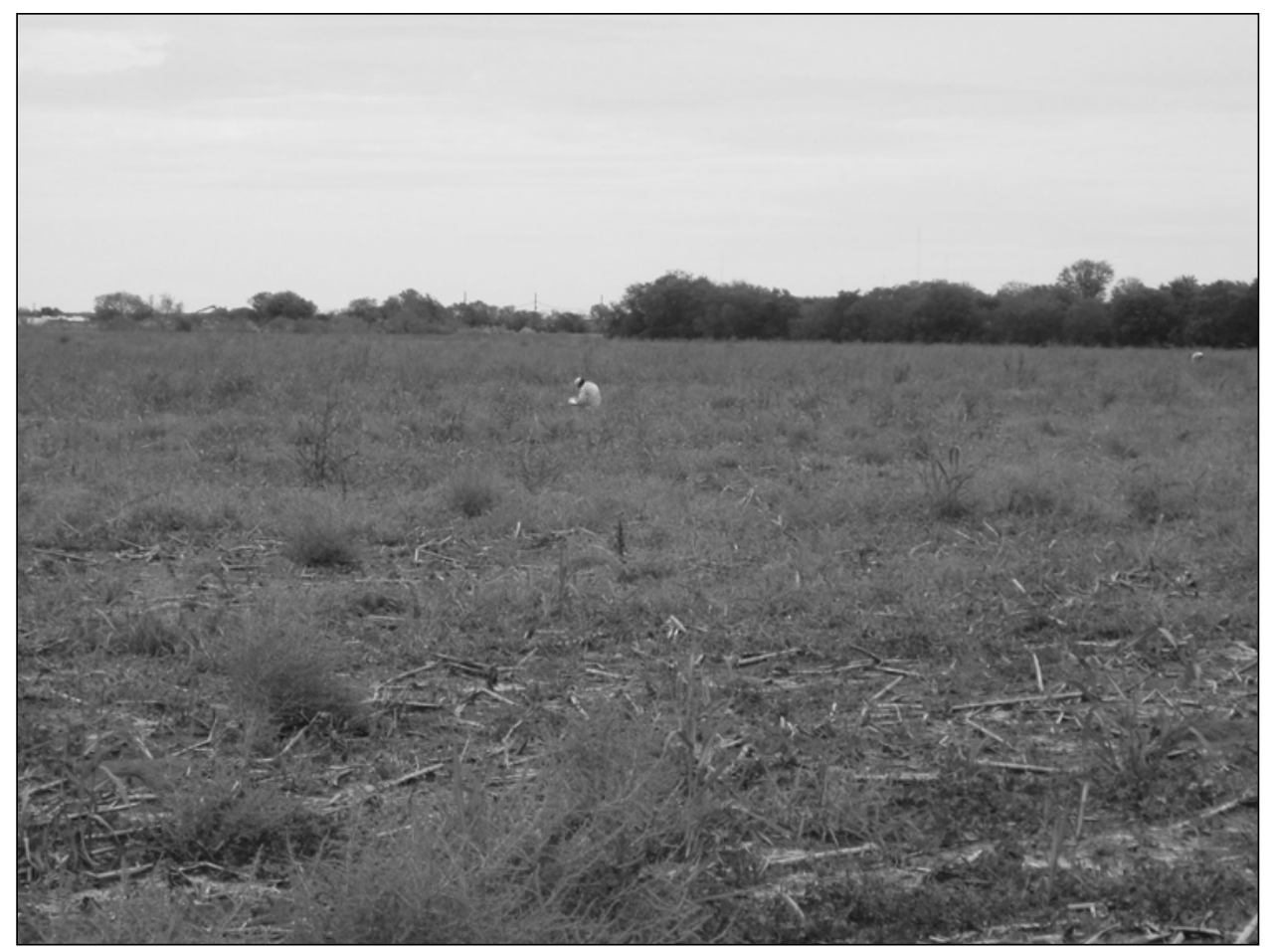

Figure 4-11. Plowed fields surveyed on Martindale AASF.

\section{Summary of Pedestrian Survey and Shovel Testing}

The survey of Martindale AASF used a 100 percent pedestrian survey accompanied by shovel testing to investigate the 121 acres of open fields surrounding the airfield. A total of 63 shovel tests were excavated resulting in a removal of $2.6 \mathrm{~m}^{3}$ of sediment. Nine artifacts $(3.5$ artifacts $/ \mathrm{m}^{3}$ ) were recovered from the shovel tests and five isolated surface finds were recorded. No features were observed on the project area. The prehistoric artifacts recovered were a distally beveled biface, possibly used as a wedge, two cores, a tested cobble and two specimens of debitage. Historic artifacts recovered consist of a cut nail, a pre-Vietnam War mess kit, a piece of farm machinery and modern trash. One site, 41BX1694, was recorded within the project area. This site consists of a scatter of burned rock, debitage, a tool and a tested cobble. Because of the disturbed nature of 41BX1694, research potential appears minimal. 



\section{Chapter 5: Summary and Recommendations}

The Center for Archaeological Research of The University of Texas at San Antonio conducted an archaeological inventory of the Army National Guard Martindale Army Aviation Support Facility located in Bexar County, Texas in November 2006 for the Adjutant General's Office. The inventory consisted of a 100 percent pedestrian survey and shovel testing of approximately 121 acres of open fields encompassing the undeveloped portion of the Army National Guard Martindale AASF. This report discussed the survey of this facility conducted between October 24 and November 3, 2006.

Because the project area is within one-half mile of the Rosillo Creek drainage, a desirable locale for prehistoric hunters and gatherers, potential exists for cultural resources. The archaeological work was conducted to determine whether buried cultural deposits exist on the airbase, to record any sites encountered, and to provide recommendations as to management and NRHP eligibility of any newly documented site.

Sixty-three shovel tests were excavated resulting in the removal of $2.6 \mathrm{~m}^{3}$ of sediment. Nine artifacts $\left(3.5 \mathrm{artifacts} / \mathrm{m}^{3}\right)$ were recovered from shovel tests and five isolated surface finds were recorded. No features were observed on the project area. In the process of conducting the survey one new site was identified and documented, 41BX1694. This site is located along the eastern boundary of the property and consists of a scatter of burned rock, debitage, a tool and a tested cobble. All of the artifacts were encountered in the top $30 \mathrm{~cm}$ of sediments. Due to the disturbed nature of the top $30 \mathrm{~cm}$ of the project area from bioturbation, rodent activity and soil tilling and to the low density of cultural materials, the site appears to retain minimal research potential. However, due to the close proximity of Rosillo Creek and the presence of alluvial soils the possibility exists for deeply buried features and/or cultural material on the eastern side of the facility. Because the survey consisted of shovel testing the upper $60 \mathrm{~cm}$ of sediments, any deeply buried deposits were not assessed. Therefore the CAR recommends that 41BX1694 be considered potentially eligible for the NRHP. 



\section{References Cited}

Barile, K. S.

2002 A Cultural Resource Survey of Segment III of the SAWS Aquifer Storage and Recovery Project, City of San Antonio, Bexar County, Texas. SWCA Cultural Resource Report No. 01-461. SWCA, Inc. Environmental Consultants, Austin, Texas.

Bexar County Clerk

2007 Public deed records (1837-1963 Historical Records, Deed Book 2057, 13 June 1944, pp. 466-468). Electronic database, <http://www.countyclerk.bexar.landata.com/>, accessed February 2007.

Black, S. L.

1986 Clemente and Herminia Hinojosa Site, 41JW8: A Toyah Horizon Campsite in Southern Texas. Special Report, No. 18. Center for Archaeological Research, The University of Texas at San Antonio.

1989 Central Texas Plateau Prairie. In From the Gulf to the Rio Grande: Human Adaptation in Central, South, and Lower Pecos Texas, by T. R. Hester, S. L. Black, D. G. Steele, B. W. Olive, A. A. Fox, K. J. Reinhard, and L. C. Bement, pp. 17-36. Research Series No. 33. Arkansas Archeological Survey, Fayetteville.

Black, S. L. and D. G. Creel

1997 The Central Texas Burned Rock Midden Reconsidered. In Hot Rock Cooking on the Greater Edwards Plateau: Four Burned Rock Midden Sites in West Central Texas, Volume I, by S. L. Black, L. W. Ellis, D. G. Creel, and G. T. Goode, pp. 269-301. Studies in Archeology 22. Texas Archeological Research Laboratory, The University of Texas at Austin. Archeology Studies Program, Report 2. Texas Department of Transportation, Environmental Affairs Division, Austin, Texas.

Black, S. L. and A. J. McGraw

1985 The Panther Springs Creek Site: Cultural Change and Continuity in the Upper Salado Creek Drainage, South-Central Texas. Archaeological Survey Report, No. 100. Center for Archaeological Research, The University of Texas at San Antonio.

Collins, M. B.

1995 Forty Years of Archeology in Central Texas. Bulletin of the Texas Archeological Society 66:361-400.

Dallas Morning News (DMN) [Dallas, Texas]

1954 "State Would Get Two U.S. Tracts." 9 August, Part II:8. Dallas, Texas.

Hester, T. R.

1995 The Prehistory of South Texas. Bulletin of the Texas Archeological Society 66:427-459.

Johnson, L. and G. Goode

1994 A New Try at Dating and Characterizing Holocene Climates, as well as Archaeological Periods, on the Eastern Edwards Plateau. Bulletin of the Texas Archeological Society 65:1-15.

Khonitz, M.

1990 Site Survey Record. Manuscript on file, Center for Archaeological Research, The University of Texas at San Antonio. 
Prewitt,E.R.

1981 Culture Chronology in Central Texas. Bulletin of the Texas Archeological Society 52:65-89.

South Central Texas Regional Water Planning Group

2006 Vegetational Areas. Electronic document, < http://www.watershedexperience.com/ish_vege_area.html >, accessed November 2006.

2006 Climate. Electronic document, <http://www.watershedexperience.com/ish_climate.html>, accessed November 2006.

Taylor, R. (editor)

1996 The New Handbook of Texas in Six Volumes. The Texas State Historical Association, Austin.

Taylor, F. B., R. B. Hailey and D. L. Richard

1966 Soil Survey of Bexar County, Texas. Soil. United States Department of Agriculture, Soil Conservation Service. Washington, D.C.

Texas Historical Commission (THC)

2006 Texas Archeological Sites Atlas. Electronic database, <http://www.pedernales.thc.state.tx.us/>, accessed September 2006.

Thompson, J.

2006 Architectural Survey of Facility No. 2: A 1950s Hangar on Martindale Army Aviation Support Facility, San Antonio, Bexar County, Texas. Manuscript on file, Center for Archaeological Research, The University of Texas at San Antonio.

United States Department of Agriculture (USDA)

2007 Plants Database. Electronic database, <http://plants.usda.gov/index.html>, accessed February 2007. 